\title{
Significant impacts of COVID-19 lockdown on urban air pollution in Kolkata (India) and amelioration of environmental health
}

\author{
Biswajit Bera ${ }^{1}$ (D) . Sumana Bhattacharjee ${ }^{2}$. Pravat Kumar Shit ${ }^{3}$ (D) . \\ Nairita Sengupta ${ }^{4}$ (D) . Soumik Saha ${ }^{5}$
}

Received: 6 June 2020 / Accepted: 18 July 2020 / Published online: 28 July 2020

(c) Springer Nature B.V. 2020

\begin{abstract}
The fatal novel coronavirus (COVID-19) pandemic disease smashes the normal tempo of global socio-economic and cultural livelihood. Most of the countries impose a lockdown system with social distancing measures to arrest the rapid transmission of this virus into the human body. The objective of this study is to examine the status of air quality during and pre-COVID-19 lockdown and to recommend some long-term sustainable environmental management plan. The pollution data like $\mathrm{PM}_{10}, \mathrm{PM}_{2.5}, \mathrm{O}_{3}, \mathrm{SO}_{2}, \mathrm{NO}_{2}$ and $\mathrm{CO}$ have been obtained from State Pollution Control Board under Govt. of West Bengal. Similarly, various land surface temperature (LST) maps have been prepared using LANDSAT-8 OLI and LANDSAT-7 ETM + images of USGS. The maps of $\mathrm{NO}_{2}$ and aerosol concentration over Indian subcontinent have been taken from ESA and NASA. The digital thematic maps and diagrams have been depicted by Grapher 13 and Arc GIS 10.3 platforms. The result shows that the pollutants like $\mathrm{CO}, \mathrm{NO}_{2}$ and $\mathrm{SO}_{2}$ are significantly decreased, while the average level of $\mathrm{O}_{3}$ has been slightly increased in 2020 during the lockdown due to close-down of all industrial and transport activities. Meanwhile, around $17.5 \%$ was the mean reduction of $\mathrm{PM}_{10}$ and $\mathrm{PM}_{2.5}$ during lockdown compared with previous years owing to complete stop of vehicles movement, burning of biomass and dust particles from the construction works. This study recommends some air pollution-tolerant plant species (in urban vacant spaces and roof tops) for long-term cohabitation among environment, society and development.
\end{abstract}

Keywords COVID-19 $\cdot$ Lockdown system $\cdot$ Air quality $\cdot$ Parameters $\cdot$ Sustainable

\author{
Abbreviations \\ COVID-19 Coronavirus diseases 2019 \\ WHO World Health Organization \\ SARS-CoV-2 Severe acute respiratory syndrome coronavirus 2
}

Electronic supplementary material The online version of this article (https://doi.org/10.1007/s1066 8-020-00898-5) contains supplementary material, which is available to authorized users.

Biswajit Bera

biswajitbera007@gmail.com

Extended author information available on the last page of the article 


$\begin{array}{ll}\mathrm{NO}_{2} & \text { Nitrogen dioxide } \\ \mathrm{SO}_{2} & \text { Sulphur dioxide } \\ \mathrm{CO} & \text { Carbon monoxide } \\ \mathrm{PM}_{10} & \text { Particulate matter } 10 \\ \mathrm{PM}_{2.5} & \text { Particulate matter } 2.5 \\ \mathrm{O}_{3} & \text { Ozone } \\ \text { CAMS } & \text { Copernicus atmosphere monitoring service } \\ \text { ESA } & \text { European space agency } \\ \text { NASA } & \text { National Aeronautics and Space Administration } \\ \text { CPCB } & \text { Central Pollution Control Board } \\ \text { USGS } & \text { United States Geological Survey } \\ \text { OLI } & \text { Operational land imager } \\ \text { ETM }+ & \text { Enhanced thematic mapper plus } \\ \text { S5P/TROPOMI } & \text { Sentinel 5 precursor/tropospheric monitoring instrument and ozone } \\ & \text { monitoring instrument } \\ \text { TM } & \text { Thematic mapper } \\ \text { TIRS } & \text { Thermal infrared sensor } \\ \text { LST } & \text { Land surface temperature } \\ \text { DN } & \text { Digital number } \\ \text { NDVI } & \text { Normalized difference vegetation index } \\ \text { GIS } & \text { Geographic information system } \\ \text { UNEP } & \text { United Nations Environment Programme } \\ \text { APTI } & \text { Air pollution tolerance index } \\ \text { VGS } & \text { Vertical greenery system }\end{array}$

\section{Introduction}

The normal rhythm of livelihood of the people exclusively world's economy, socio-cultural compatibility, national and international political waves, academic atmosphere, and moreover people's regular lifestyle has been incredibly disrupted due to the fatal novel coronavirus (COVID-19). The outbreak of catastrophic coronavirus (COVID-19) occurred during the end of December 2019 and creates the gigantic turmoil particularly in socio-economic backbone of the nations (Tian et al. 2020; Wang et al. 2020a, b). The novel coronavirus has been emerged as an extraordinary disastrous influence worldwide. On December 29, 2019, this new infectious disease was first identified at Wuhan City, the capital of Hubei Province in China (Huang et al. 2020a, b; Zhou et al. 2020a, b; Zhu et al. 2020). After detecting a lot of positive cases throughout the country, the Government of China imposed countrywide lockdown system to regulate the transmission of infectivity and wanted to reduce the excessive pressure on health infrastructure (Wilder-Smith and Freedman 2020). The World Health Organization (WHO) authenticated the fact related with the contagious nature of coronavirus through human globules inhalation during January 2020 (WHO 2020e).WHO has declared that the COVID-19 is a sixth Public Health Emergency of International Concern (on January 30, 2020) because of the enormous aftermath of this fatal disease throughout the world (Wee et al. 2020; WHO 2020c). The global transmission of coronavirus (COVID-19) and its harmful impacts have been started to transmit through human interaction from February 2020. Many relevant studies revealed that COVID-19 is a severe respiratory infectious disease which can attack the whole respiratory system and 
lungs of human being (Gautam and Trivedi 2020; Chen et al. 2020). Italian Institute of Health clearly notified that around 481 people, who were previously suffering due to acute illness, have now lost their lives because of the attack of fatal COVID-19 (Gautam 2020a). In this context, the old-age persons are considered to be extremely vulnerable as the rate of contagion and mortality are noticeably higher in this age group ( $\geq 65$ years) (Zhou et al. 2020a, b; Gautam and Hens 2020).

As the COVID-19 disease has been originated from the novel coronavirus SARS-CoV-2, WHO declared as COVID-19 a pandemic on March 11, 2020 (WHO 2020d). Coronavirus has snatched 3,00,000 lives including 4.5 million confirmed cases around 216 countries across the world as of May 15, 2020 (WHO 2020a). The social distancing measure has been enforced by Chinese Government and it is widely accepted as a compulsory defensive technique to deal with coronavirus pandemic whenever there is no other substitute to combat against this lethal disease (Huang et al. 2020a, b; Zhang et al. 2020). Almost half population of the world has compelled to sustain their lives under lockdown system since the end of March 2020 (Tosepu et al. 2020). In this context, it is noteworthy that India has enlisted as a hot spot point in the list of COVID-19 affected Asian countries where 81,970 confirmed cases and 2649 deaths have been recorded as of May 15, 2020 (https://covid 19india.org). At the end of January 2020, the first COVID-19 positive case had been identified in Kerala state of India and the infected person who travelled from China (Gautam and Hens 2020). In India, Maharashtra, Tamil Nadu and Delhi are the leading states in terms of total confirmed cases, whereas Meghalaya, Sikkim and Mizoram witness very few numbers of COVID-19 cases (covid19india.org). The honourable Prime Minister of India appealed to the citizens for effective implementation of lockdown system. To prevent rapid transmission of coronavirus, countrywide lockdown had been enforced through the halting of economic production and restrictions on mobility of the citizens (Gautam and Hens 2020). In India, West Bengal has witnessed the brutal strike of coronavirus with surging growth rate of confirmed cases, whereas Kolkata (the capital of West Bengal) is recognized as the epicentre of COVID-19 pandemic in the state (Fig. 1). Government of India has already implemented lockdown rules and enacted social distancing norms from March 24,2020 , and it is further continued up to May 31, 2020, to manage the rapid outbreak of COVID-19 pandemic during global emergency. Among the highly COVID-19 affected states in India, West Bengal stands at a vulnerable situation with 2461 confirmed cases till May 15, 2020, and Kolkata (the capital of West Bengal) is severely affected due to COVID-19 pandemic and is the epicentre of the state (Health and Family Welfare Department, Govt. of West Bengal 2020). Here, the basic problem is that the COVID-19 infection rate and numbers of deaths are frequently increasing day by day in Kolkata City due to co-morbidity of the people such as respiratory disease and chronic obstructive pulmonary disease. World Health Organization (WHO 2020a, b, c, d, e) also gave clear assertion that the major diseases like respiratory disease (26\%), chronic obstructive pulmonary disease (25\%) and stroke and ischaemic heart (17\%) occurred due to severe air pollution. Kolkata, the third densely populated region of India, is the home of 4.5 million populations (Census of India 2011). In terms of urban air pollution, Kolkata is designated as dusty city (Kumar and Singh 2003) and it is enlisted in the World's 25 most polluted cities along with 10 worse polluted cities in India (WHO 2011). The Central Pollution Control Board of India (2012) had reported that the Eastern economic pivot (Kolkata) of India is registered as worse polluted city with respect to air pollution and the city is almost equivalent to Delhi (Das et al. 2015) in comparison with another major metropolitan cities like Mumbai, Bengaluru, Chennai, Hyderabad, etc. It must be estimated that the quantity of respiratory and allergic illness would be increased because of the rapid alteration of air 

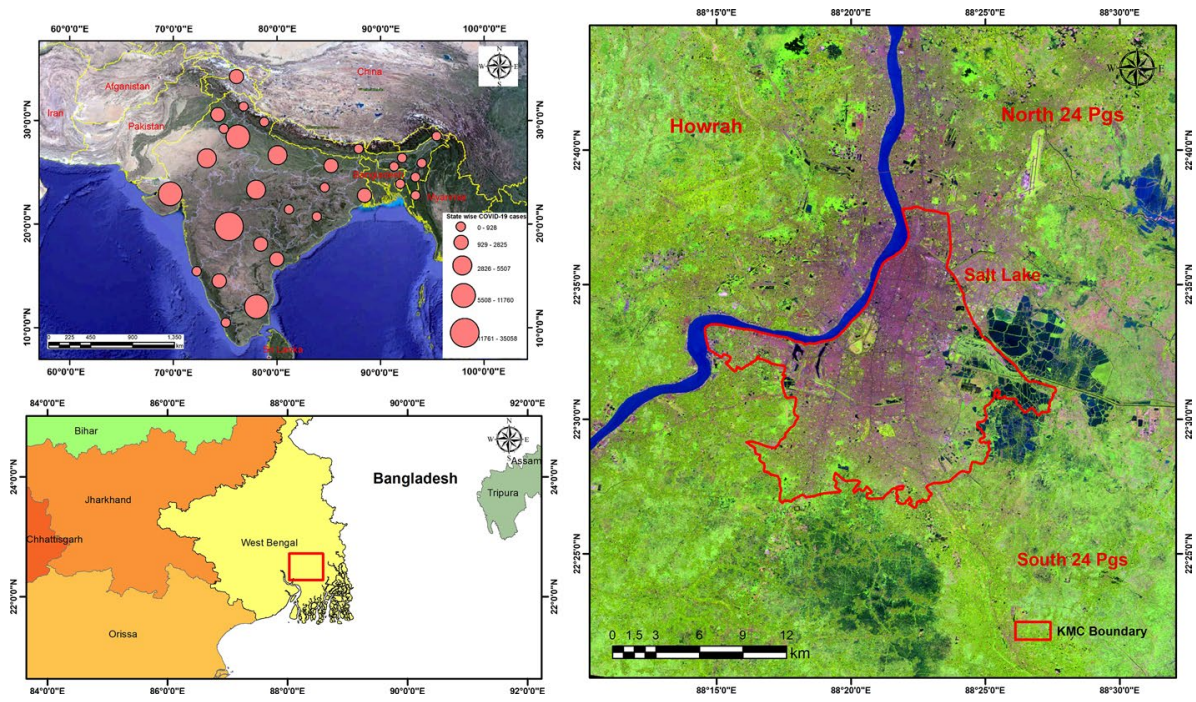

Fig. 1 Geographical distribution of COVID-19 cases all over India (as of May 15, 2020) and location of the study area

quality in Kolkata City. So, the main objective of this study is to evaluate the status of air quality standard during and pre-COVID-19 lockdown phase in Kolkata City of India and to recommend long-term sustainable environmental management plan. Although, most of the people of the world have not previously experienced long-term lockdown system but at the same time due to close-down of transport, constructional works and industrial activities, the health of the total environment including humans have been slightly improved. The study has great significance in this present-day context that during lockdown phase how much air pollution is reduced and this scientific study has also been identified the specific sources of air pollution. The uniqueness of the study reflects actual ground truth regarding air quality standards and public health conditions during and pre-lockdown phase. The deadly COVID-19 pandemic global emergency gives a huge scope to scientists, administrators and policymakers for rethinking about the rejuvenation of environmental health. The policymakers can implement the sustainable environmental management plan which has been prescribed through this study and such type of scientific fundamental research work will definitely help to build simulation model for improving environmental sustainability. Most of the recent studies have been nicely articulated on assessment of air quality standard, status of total environment and reasons behind fluctuations of particular pollution parameter with relation to COVID-19 during and pre-lockdown phase, while this study has tried to examine not only status of air quality but also long-term sustainable environmental management plan. Similarly, the strength of the study has also been amplified because it has been validated through the concentration maps of $\mathrm{NO}_{2}$ and aerosol over Indian subcontinent depicted by European Space Agency (ESA) and National Aeronautics and Space Administration (NASA) during and pre-lockdown phase. Meanwhile, the study has been effectively completed considering some limitations like inadequate automatic air quality measurement stations, non-working manual stations and limited interaction with experts and laboratory assistance during COVID-19 pandemic situation. 


\section{Air quality scenarios of Europe and Asian countries during COVID-19 pandemic}

As the industrial activities, manufacturing, power and transport sectors are almost stopped during lockdown period, the environment is stressed out from the burden of alarming anthropogenic nuisance. It must be an inevitable fact that the global economy and health safety of mankind fight against dreadful impact of coronavirus, while restricted economic activities and human actions remarkably reduce the pollution level (Dutheil et al. 2020). During the lockdown period, the release of $\mathrm{NO}_{2}, \mathrm{SO}_{2}$ and $\mathrm{PM}_{2.5}$ has been dwindled than the high emission rate of 2019 at Yangtze river delta region in China (Li et al. 2020). Similarly, the significant reduction of $\mathrm{CO}, \mathrm{NO}_{2}$ and $\mathrm{PM}_{2.5}$ level (by 49\%, 35\% and 21\%) has been recorded in the quarantine session across Almaty, Kazakhstan with respect to the previous year (Kerimray et al. 2020). It has been reported that the concentration level of $\mathrm{NO}_{2}$ and $\mathrm{PM}_{2.5}$ was very low in the lower atmosphere of major cities of China (during lockdown) due to partially shut down of different industries (ESA 2020c; CAMS 2020). Beside this, the air quality of the European countries is amazingly upgraded due to limited anthropogenic activities during the prevalence of COVID-19 global pandemic (ZambranoMonserrate et al. 2020). The global air quality standard and health of total environment are recovered to some extent for controlled vehicles movement, limited usage of fuel energy and partially closed industrial sectors, etc. (Muhammad et al. 2020). A study is focussed that the concentration of $\mathrm{NO}_{2}$ is vibrantly reduced by 20-30\% in France, Spain, Italy and Germany during lockdown phase (ESA 2020b). A comparative study (year 2019 and 2020) shows that the $\mathrm{NO}_{2}$ emission rate is dramatically fallen (30\% reduction) in the year 2020 compared with 2019 at Wuhan City in China (NASA 2020a). In this context, it is noteworthy that the reduction of emissions of different pollutants from industrial and transport sector is not prolific to avert acute air pollution level in China due to the worse meteorological conditions (Wang 2020).

In this context, the discharge of manufacturing waste, emission of greenhouse gasses, release of poisonous particulates and combustion of coal and petroleum have been curtailed due to the pausing of industrial production, vehicles movement and power generation during lockdown period which promote pollution free sky in city areas, revitalization of ozone layer, declining of pollution status in different tourist spots as well as the restoration of entire ecosystem enormously (Chakraborty and Maity 2020). Gautam (2020a) has assessed the modifications of $\mathrm{No}_{2}$ concentration over the different Asian countries during COVID-19 emergency condition where $\mathrm{NO}_{2}$ level is lowered by $20-30 \%$ in China and $70 \%$ in India. Furthermore, the various countries of Europe experience a sharp dissimilarity in terms of $\mathrm{NO}_{2}$ emission during pre- and post-COVID-19 disaster. It must be stated that the efficacy of lockdown is more vibrant in Asian states compared with European nations on the basis of the drop of $\mathrm{NO}_{2}$ during lockdown period (Gautam 2020a). The share of $\mathrm{SO}_{2}$, $\mathrm{NO}_{2}, \mathrm{CO}_{2}, \mathrm{O}_{3}, \mathrm{PM}_{10}$ and $\mathrm{PM}_{2.5}$ during the month of March and April 2020 across the 22 cities in India has been compared with the concentration level of these parameters during the same time period in 2017 and the study reflects the positive modifications of air quality during March and April in 2020 (Sharma et al. 2020). It is evident that various preventive measures with social distancing norms have been taken to regulate the transmission of COVID-19 pandemic, whereas these preventive measures directly affect the growth of global economy, human health and environment (Sarkodie and Owusu 2020). Similarly, another study established that social distancing rule is the most effective way for administration to regulate the contagious nature of COVID-19 pandemic in India (Bherwani et al. 
2020). It is undoubtedly observed that the per day emission rate from road traffic sector was the lowermost on the day of national Janta Curfew in India (CPCB 2009, 2020). After the initiation of lockdown, the average concentration of $\mathrm{PM}_{2.5}$ was decreased up to $26 \mu \mathrm{g} /$ $\mathrm{m}^{3}$ on March 27, 2020, from $91 \mu \mathrm{g} / \mathrm{m}^{3}$ on March 20, 2020, in New Delhi and it is indicating that around $71 \%$ reduction of this particulate matter in the atmosphere (CPCB 2020; Mate et al. 2020; Mitra et al. 2020). It must be stated that the upgrading qualitative status in the all spheres of environment is the certain aftermath of lockdown phase (Gautam 2020a). The long-term lockdown system becomes effective to diminish the materialistic consumption and energy usage (Jribi et al. 2020). There is a prominent decline in utilization of renewable energy source, i.e. coal consumption during the first half of 2020 in comparison with the preceding years (Eroglu 2020). Subsequently, it has been recorded that the pollutants in the major metropolitan cities of India (namely Mumbai, Kolkata, Bengaluru and Chennai) have been tremendously decreased during the lockdown phase (CPCB 2020; Sharma et al. 2020; Lau et al. 2020). It is evident that there is an inter-relation between the ambient air quality indicators and different meteorological factors, e.g. temperature (Bashir et al. 2020). The contemporary research on bio-aerosol reflects the hazardous impact on human health in international and regional level (Humbal et al. 2020, 2018). It must be mentioned that the share of earlier fatality caused by life-threatening air pollution is substantially decreased in India due to enormous depletion of aerosol accumulation during lockdown phase (Gautam 2020b). The excessive concentration of greenhouse gasses controls the temperature variation in the lower atmosphere, whereas lower accumulation of $\mathrm{CO}, \mathrm{NO}_{2}, \mathrm{SO}_{2}, \mathrm{PM}_{10}$ and $\mathrm{PM}_{2.5}$ may modify the intensity of surface air temperature. The Meteorologists have explained that high emission rate of greenhouse gases has been significantly controlled due to global lockdown which seems to be an unusual phenomenon after World War II (Global Carbon Project 2020).

\section{Methods and material}

\subsection{Data sources and data acquisition}

In this study, six parameters like $\mathrm{CO}, \mathrm{NO}_{2}, \mathrm{SO}_{2}, \mathrm{O}_{3}, \mathrm{PM}_{10}$ and $\mathrm{PM}_{2.5}$ have been considered to evaluate the deviation of air quality during lockdown and pre-lockdown period. The concentrations of these parameters have been compared between the lockdown session during March 25 to May 15, 2020, and the similar time frame in preceding 3 years $(2017,2018$ and 2019). Hourly emission levels of above-mentioned selected pollution parameters have been obtained on daily basis from the State Pollution Control Board under Govt. of West Bengal. The day-wise data (4 years) have been collected to monitor the changing pattern of the concentration level of the above said parameters. The stations like Fort William, IACS Jadavpur, Rabindra Bharati University, Rabindra Sarobar and Victoria Memorial have been selected from the Metropolitan City Kolkata due to availability of pollutionrelated data. Moreover, LANDSAT 8 OLI and LANDSAT 7 ETM + images (path 138, row 44 and resolution $30 \mathrm{~m}$ ) of the United States Geological Survey (USGS) have been used to prepare land surface temperature mapping for analysing the temperature variation before and after lockdown. The maps regarding variation of $\mathrm{NO}_{2}$ and aerosol concentration over India during lockdown and pre-lockdown phase have been obtained from European space agency (ESA) and the National aeronautics and Space Administration (NASA) individually (ESA 2020a; NASA 2020b). Here, ESA has captured the data of $\mathrm{NO}_{2}$ concentration using 
Copernicus Sentinel-5 Precursor Tropospheric Monitoring Instrument (S5P/TROPOMI). During lockdown phase, some technical limitations have been faced like limited automatic data collection stations and laboratory-based analysis. With the advancement of science and technology, there are various simulation models and modern devices which have been designed to quantify area-time-specific pollutants concentration and magnitude of dispersal. Despite the fact, the merit of this scientific study is to determine the short-term impacts of COVID-19 on urban air pollution in Kolkata City and long-term sustainable management plan using ground automatic stations data, satellite imageries, RS\&GIS and descriptive statistical techniques. The study of significant impacts (of COVID-19 lockdown) on urban air pollution has been authenticated through the maps of concentration of $\mathrm{NO}_{2}$ and aerosol over Indian subcontinent prepared by European space agency (ESA) and National aeronautics and Space Administration (NASA).

\subsection{Data analysis}

\subsubsection{Application of RS \& GIS techniques}

The diurnal and monthly average of selected parameters at every station has been calculated of all over Kolkata City during (in 2020) and pre-lockdown years 2017, 2018 and 2019. The spatio-temporal variation of different components and their percentages has been calculated to understand the changing nature of the air quality. The graphical representations have been prepared on the basis of the daily average of these parameters during the sampling periods through Grapher 13 software. The different digital thematic maps have been prepared on Arc GIS 10.3 platform.

\subsubsection{Statistical analysis}

The diverse multivariate statistical methods such as hierarchical cluster analysis (HCA) and principal component analysis (PCA) have been employed using IBM SPSS (16.0) statistical software to examine the significance of the selective air pollution parameters of Kolkata City. It is an algorithm which makes class between similar objects and it analyses the similarity or dissimilarity between the variables. In hierarchical cluster analysis, the similarity is drawn by various proper metrics with linkage principle. A few common metrics have been applied (between a \& b variables) in HCA system. These are as follows

$$
\text { Euclidean distance }\|a-b\|_{2}=\sqrt{\sum_{i}(a-b)^{2}}
$$

Squared Euclidean distance $\|a-b\|_{2}^{2}=\sum_{i}\left(a_{i}-b_{i}\right) 2$

$$
\text { Manhattan distance }\|a-b\|_{1}=\sum_{i}\left|a_{i}-b_{i}\right|
$$

Maximum distance $\|a-b\| \infty=\max _{i}\left|a_{i}-b_{i}\right|$. 
Subsequently, PCA generates a pattern between the variables. PCA has been performed considering six different parameters of air quality standard in pre- and during lockdown and PCA mainly represents the dataset more reliable. The PCA is done through some mathematical algorithms. The following steps have been considered to analyse the relationship among the variables. These are as follows:

- Standardization

- Covariance matrix

- Computation of eigenvector and value.

$$
\left.x_{\text {new }}=\frac{x-\mu}{\sigma} \quad \text { (For standardization }\right)
$$

where $X$ is the initial, whereas $\mu$ and $\sigma$ represent mean and SD.

For population

$$
\operatorname{Cov}(x, y)=\frac{\sum\left(x_{i}-x\right) \times\left(y_{i}-y\right)}{N} \quad \text { (For Covariance matrices) }
$$

For Sample

$$
\begin{gathered}
\operatorname{Cov}(x, y)=\frac{\sum(x i-\bar{x}) \times(y i-\bar{y})}{N-1} \\
A v-\lambda v=0 ;(A-\lambda \mathrm{I}) v=0 \quad(\text { Eigenvector and values for matrix A) } \\
\operatorname{det}(A-\lambda \mathrm{I})=0 .
\end{gathered}
$$

\subsubsection{Detection of land surface temperature variation}

When the temperature of the earth surface features is higher than the absolute zero $\left(-273^{\circ} \mathrm{C} / 0 \mathrm{~K}\right)$, then each object radiates thermal electromagnetic energy and in addition to LST of different objects has been determined. The signals are received through different sensors like TM, ETM, TIRS and these signals are transformed into sensor radiance.

The different methods are available for the extraction of accurate LST, whereas these methods are invented by Landsat Project Science Office (LPSO 2002). The transformation of DN values into reflectance values has been accomplished through the application of radiometric correction. For the extraction of the Top of Atmospheric Radiance (TAR), the LANDSAT 8 OLI and LANDSAT 7 ETM + band data have been converted using the following formula:

$$
L \lambda=M_{L} * Q_{\text {cal }}+A_{L}-O_{i}
$$

where $L \lambda=$ Top of Atmospheric Radiance, $M_{L}=$ band-specific multiplicative rescaling factor, $Q_{\text {cal }}=$ Band10 image, $A L=$ band-specific additive rescaling factor and $O i=$ correction for Band10.

Then, the brightness temperature has been measured using the thermal constant extracted from metadata file for conversion of radiance to at-sensor temperature. The following equation has been applied 


$$
B T=K 2 / \ln [(K 1 / L \lambda)+1]--273.1515
$$

where $\mathrm{BT}=$ brightness temperature. $K_{1}$ and $K_{2}=$ band-specific thermal conversion constants from the metadata file of the downloaded image.

NDVI is regarded as an imperative tool for LST calculation because the proportion of vegetation (PV) is interrelated with NDVI. The calculation has been done with the help of following equation

$$
\mathrm{NDVI}=\mathrm{NIR}-R / \mathrm{NIR}+R
$$

where NIR = near-infrared band (Band5) and $\mathrm{R}=$ red band (Band4).

The following formula has been used to calculate the proportion of vegetation (PV)

$$
\mathrm{PV}=\left(\mathrm{NDVI}-\mathrm{NDVI}_{s}\right) /(\mathrm{NDVI} v) .
$$

The emissivity of every pixel has been measured from the PV value. The land surface emissivity has been derived using the following formula

$$
\varepsilon \lambda=\varepsilon V_{\lambda} P v+\varepsilon_{s} \lambda(1-P v)+C_{\lambda}
$$

where $\varepsilon_{\lambda=}$ Land surface Emissivity, $\varepsilon_{\mathrm{V}=}$ vegetation emissivity, $\varepsilon_{s}=$ soil emissivity, $C=$ surface roughness ( $C=0$ for homogenous and flat surfaces) considered as a constant value of 0.005 (Sobrino and Raissouni 2000).

Finally, the extraction of LST has been executed using the following equation

$$
T_{s}=\mathrm{BT} /[1+\{(\lambda \mathrm{BT} / \rho) \cdot \ln \varepsilon \lambda\}]
$$

where $T_{s}=\mathrm{LST}$ in Celsius $\left({ }^{\circ} \mathrm{C}\right), \mathrm{BT}=$ brightness temperature, $\lambda=$ wavelength of emitted radiance $(\lambda=10.895), \varepsilon_{\lambda}=$ calculated emissivity.

After the computation of LST during the sampling time period, LST mapping has been performed on the platform of Arc GIS 10.3 to compare the modification of land surface temperature between lockdown phase and pre-lockdown. Furthermore, the range of temperature variability has been depicted by the graphical representation using MS Excel 2016.

\section{Results}

\subsection{Changing trend of $\mathrm{CO}, \mathrm{NO}_{2}, \mathrm{SO}_{2}$ and $\mathrm{O}_{3}$ during and pre-lockdown phase over Kolkata City}

The qualitative aspect of air is recognized as an indispensable criterion for the health-related issues of human being, while $91 \%$ population of the world survives in the areas where the inferior air quality surpasses the desirable limit (WHO 2016). The concentration of $\mathrm{NO}_{2}$ and aerosol has been massively reduced over India in the lockdown period compared with the prior years (Figs. 2, 3). The average level of $\mathrm{CO}, \mathrm{NO}_{2}$ and $\mathrm{SO}_{2}$ is significantly decreased in the year 2020 during the lockdown phase (March 25 to May15) compared with the identical time period from 2017 to 2019 (Table 1). From March 25 to March 31 in 2017, 2018 and 2019, the average concentration levels of $\mathrm{CO}$ were $0.63 \mathrm{mg} / \mathrm{m}^{3}, 0.59 \mathrm{mg} / \mathrm{m}^{3}$ and $0.63 \mathrm{mg} / \mathrm{m}^{3}$, respectively, whereas in the same months in 2020 the average $\mathrm{CO}$ concentration has been reduced up to $0.59 \mathrm{mg} / \mathrm{m}^{3}$ (Table 1; Fig. 4; Supplemental Materials S1, S2, S3 and S4). The similar 

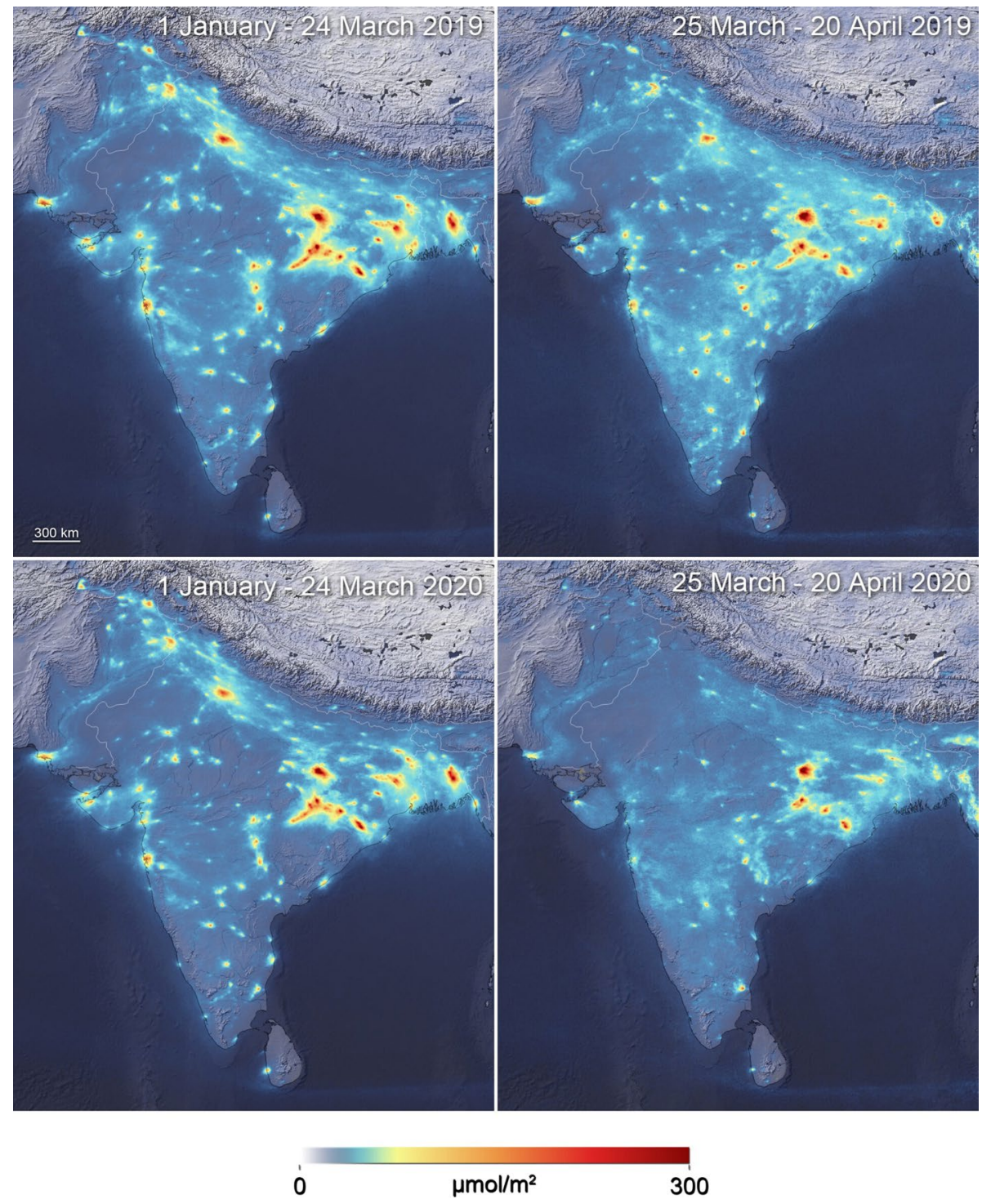

Fig. $2 \mathrm{NO}_{2}$ emission over India before (January 1-April 20, 2019) and during (January 1-April 20, 2019) lockdown session

scenario is observed during April and May (up to May 15) of 2020 when the share of CO is radically dropped up to $6.34 \%$ and $6.88 \%$, respectively, from April and May (up to May 15) of 2019 (Table 2). It is surprisingly noticed that highest monthly average concentration level of $\mathrm{CO}$ was $34.88 \%$ in May 2018 during pre-lockdown, while the maximum monthly average decrease in CO (14.99\%) has been recorded in May 2020 during lockdown period (Table 2). On the other hand, the reduction rate of $\mathrm{NO}_{2}$ is highest (12.98\%) in the month of April 2020 throughout the lockdown periods, whereas the maximum amount of $\mathrm{NO}_{2}$ emission $(40.19 \%)$ was measured in March 2019 (Table 2). The month-wise concentration of mean $\mathrm{NO}_{2}$ has been 


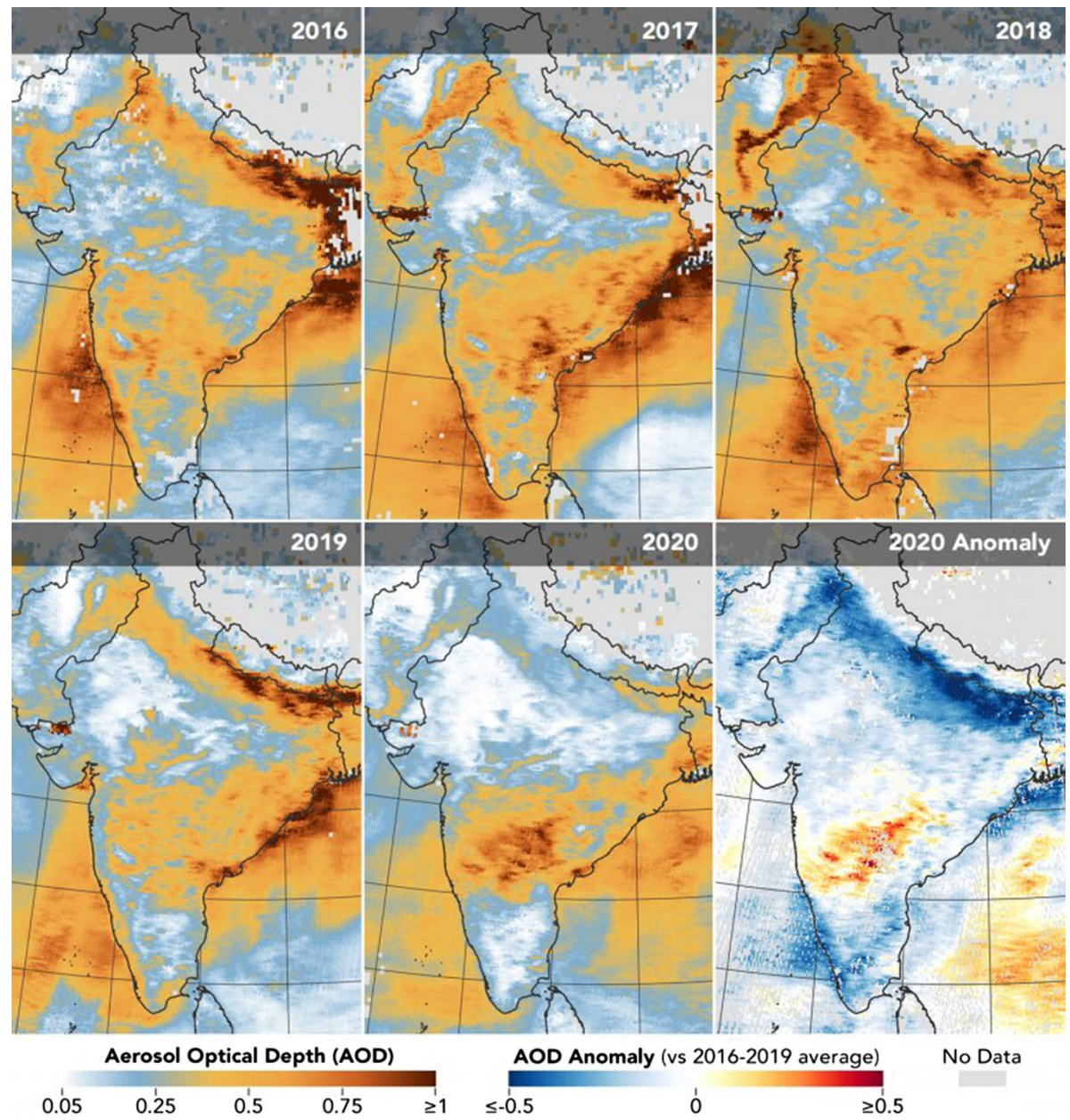

Fig. 3 The variation of aerosols optical depth (AOD) over Indian subcontinent from 2016 to 2020 and spatio-temporal anomaly of AOD in 2020 compared with 2016-2019

declined up to10.66 $\mu \mathrm{g} / \mathrm{m} 3$ in May 2020 from $24.74 \mu \mathrm{g} / \mathrm{m} 3$ in May 2017 (Table 1; Fig. 4; Supplemental Materials S1, S2, S3 and S4). It is focused that about $19.46 \% \mathrm{NO}_{2}$ is reduced during the quarantine phase in Kolkata, while emission of $\mathrm{NO}_{2}$ is dwindled by $22.79 \%$ from March $2019\left(41.58 \mu \mathrm{g} / \mathrm{m}^{3}\right)$ to March $2020(18.01 \mu \mathrm{g} / \mathrm{m} 3)$ (Tables 1, 2). Beside this, the slashing trend of another crucial pollutant $\left(\mathrm{SO}_{2}\right.$ ) has been registered throughout the lockdown period in this overcrowded city of India. In April of 2018, the accumulation of $\mathrm{SO}_{2}$ in the lower atmosphere was $9.47 \mu \mathrm{g} / \mathrm{m} 3$, whereas the quantity has been diminished up to $5.36 \mu \mathrm{g} / \mathrm{m} 3$ in the same month of 2020 (Table 1; Fig. 4; Supplemental Materials S1, S2, S3 and S4). Around 13.4\% drop of this lethal gaseous substance $\left(\mathrm{SO}_{2}\right)$ occurred during this critical period. In the same way, the extreme concentration of $\mathrm{SO}_{2}(42.92 \%)$ had been recorded in May of 2017, while during the lockdown, the highest emission of $\mathrm{SO}_{2}$ (30.41\%) has been found in March of 2020 (Table 2). Moreover; it is an exceptional incident that the density of $\mathrm{O}_{3}$ has been amplified in Kolkata during this ongoing lockdown period. The result shows that the concentration of $\mathrm{O}_{3}$ 
Table 1 Emission level of selective pollutants (monthly average) during lockdown and pre-lockdown phase in Kolkata City

\begin{tabular}{llllllll}
\hline Year & Month & \multicolumn{7}{l}{ Monthly Average of emission of selective pollutants } \\
\cline { 3 - 7 } 2017 & & $\mathrm{CO}\left(\mathrm{mg} / \mathrm{m}^{3}\right)$ & $\mathrm{NO}_{2}\left(\mu \mathrm{g} / \mathrm{m}^{3}\right)$ & $\mathrm{SO}_{2}\left(\mu \mathrm{g} / \mathrm{m}^{3}\right)$ & $\mathrm{O}_{3}\left(\mu \mathrm{g} / \mathrm{m}^{3}\right)$ & $\mathrm{PM}_{10}\left(\mu \mathrm{g} / \mathrm{m}^{3}\right)$ & $\mathrm{PM}_{2.5}\left(\mu \mathrm{g} / \mathrm{m}^{3}\right)$ \\
\hline & March & 0.63 & 20.19 & 8.21 & 51.78 & 85.09 & - \\
& April & 0.59 & 29.15 & 7.59 & 62.01 & 777.95 & - \\
2018 & May & 0.68 & 24.74 & 10.24 & 64.65 & 67.01 & - \\
& March & 0.59 & 23.69 & 7.74 & 28.81 & 92.78 & 44.38 \\
& April & 0.63 & 24.21 & 9.47 & 44.18 & 65.26 & 32.84 \\
& May & 0.83 & 20.47 & 4.27 & 54.61 & 63.40 & 37.91 \\
& March & 0.63 & 41.58 & 9.13 & 43.56 & 103.21 & 67.62 \\
& April & 0.54 & 25.55 & 8.27 & 28.08 & 75.79 & 42.20 \\
& May & 0.52 & 16.48 & 6.82 & 31.92 & 88.99 & 34.81 \\
& March & 0.59 & 18.01 & 10.96 & 53.48 & 71.70 & 42.82 \\
& April & 0.40 & 11.77 & 5.36 & 45.56 & 44.79 & 24.32 \\
& May & 0.36 & 10.66 & 2.54 & 38.68 & 35.66 & 16.86 \\
\hline
\end{tabular}
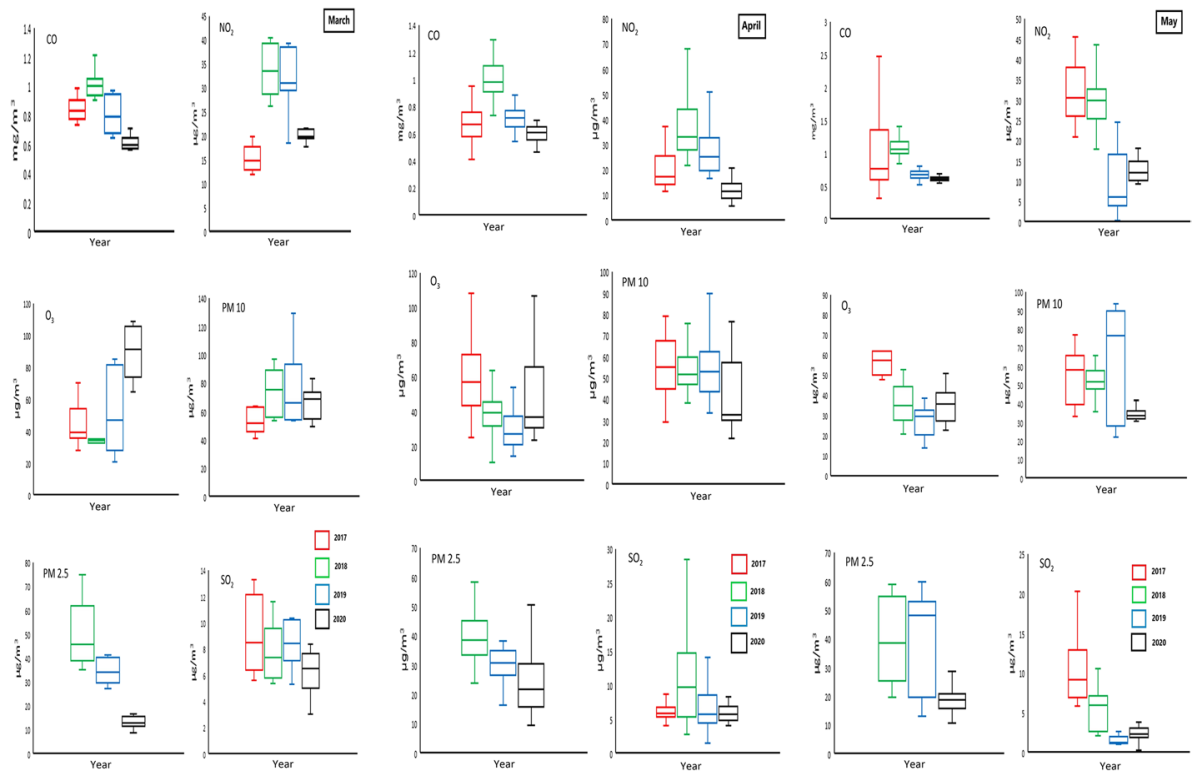

Fig. 4 The changing trend of $\mathrm{CO}, \mathrm{NO}_{2}, \mathrm{SO}_{2}, \mathrm{O}_{3}, \mathrm{PM}_{10}, \mathrm{PM}_{2.5}$ within the sampling period (March 25-May 15) during and pre-lockdown phase (2017-2020)

is boosted up to $9.73 \%$ in April of 2020 and the similar increasing trend has been reported in March and May of 2020 compared with 2019 (Table 2, Fig. 4). The quantity of $\mathrm{O}_{3}$ was $28.08 \mu \mathrm{g} / \mathrm{m} 3$ in April 2019, while it has been increased up to $45.56 \mu \mathrm{g} / \mathrm{m}^{3}$ in this particular month of 2020 (Table 1; Fig. 4; Supplemental Materials S1, S2, S3 and S4) and it is representing the rebounding tendency of this significant parameter of air quality in Kolkata. 


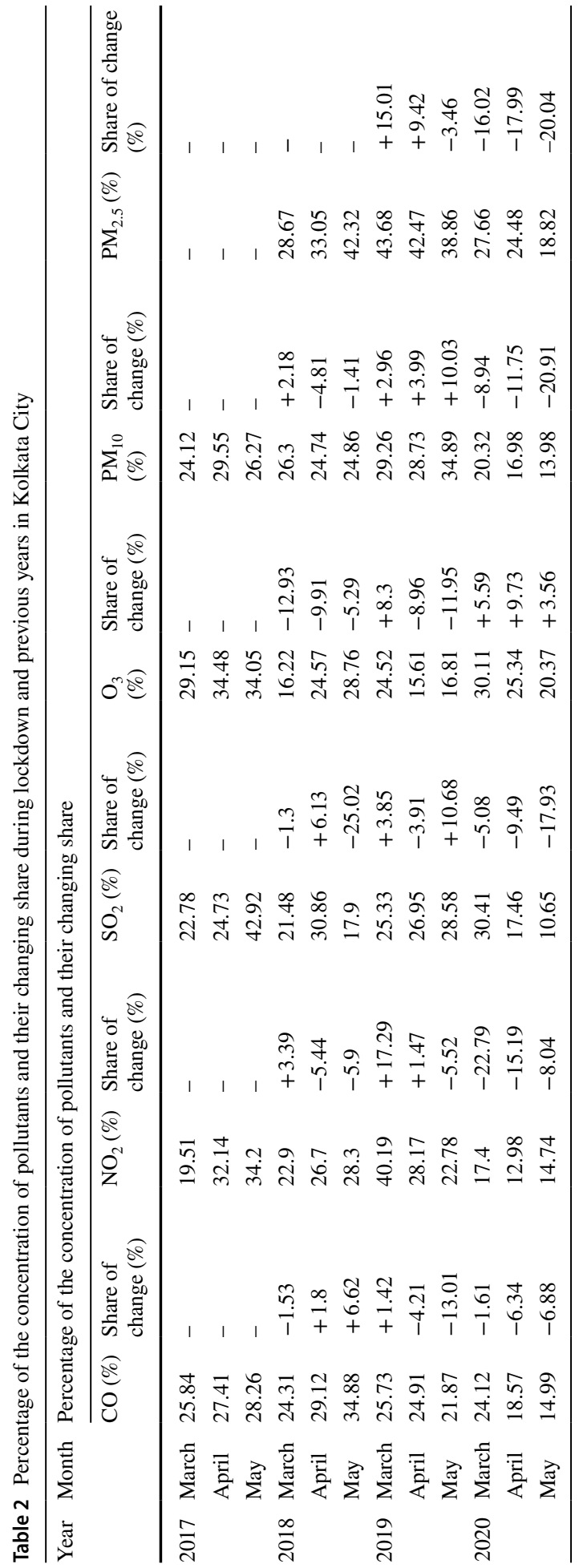




\subsection{Fluctuation of the concentration of suspended particulate matters $\left(\mathrm{PM}_{10}\right.$ and $\mathrm{PM}_{2.5}$ )}

The concentration of suspended particulate matters above $100 \mu \mathrm{g} / \mathrm{m}^{3}$ in the lower atmosphere is injurious for the health of human being (WHO 2006). The continuous dropping of $\mathrm{PM}_{10}$ and $\mathrm{PM}_{2.5}$ has been recorded from March 25 to May 15, 2020, in comparison with the preceding 3 years (2017-2019). During the lockdown phase in the year 2020, the monthly average concentration of $\mathrm{PM}_{10}$ is varied from 13.98 to $20.32 \%$ (Table 2). Just during the initiation of lockdown (in the end of March 2020), $\mathrm{PM}_{10}$ level is dropped to 8.94\% in comparison with 2019 and the magnitude of reducing trend becomes sharply vibrant through the lockdown months (Table 2). $\mathrm{PM}_{10}$ is reduced by $11.75 \%$ and $20.91 \%$ in April and May of 2020, respectively, from same months of the year 2019 (Table 2). The maximum monthly average quantity of this suspended pollutant $\left(103.21 \mu \mathrm{g} / \mathrm{m}^{3}\right)$ was found in March 2019, while the highest average concentration of $\operatorname{PM}_{10}\left(71.70 \mu \mathrm{g} / \mathrm{m}^{3}\right)$ is measured in March 2020 throughout the continuing lockdown (Table 1; Fig. 4; Supplemental Materials S1, S2, S3 and S4). Moreover, throughout the lockdown, the extreme decrease in $\mathrm{PM}_{10}$ emission $\left(35.66 \mu \mathrm{g} / \mathrm{m}^{3}\right)$ has been recorded in May 2020. Similarly, in May of 2020, $\mathrm{PM}_{2.5}$ is decreased up to $23.5 \%$ compared with May 2018 (Table 2). During the lockdown period in Kolkata, the maximum reduction of $\mathrm{PM}_{2.5}$ is recorded around $16.86 \mu \mathrm{g} / \mathrm{m} 3$ in May, whereas during pre-lockdown scenario, the maximum accumulation of this suspended particulate matter was registered around $67.62 \mu \mathrm{g} /{ }^{\mathrm{m} 3}$ in March of 2019 (Table 1; Fig. 4; Supplemental Materials S1, S2, S3 and S4). The decline of $\mathrm{PM}_{2.5}$ in lockdown phase has been restricted within the range of $16.86-42.82 \mu \mathrm{g} / \mathrm{m}^{3}$ which reflects approximately $16-20 \%$ reduction in comparison of $\mathrm{PM}_{2.5}$ in 2019 (Tables 1, 2).

\subsection{Impact of air quality change on land surface temperature}

The LST records illustrate the distinct variation of surface temperature of Kolkata City between lockdown and pre-lockdown situation. The study portrays that there is a prominent reduction of surface temperature due to the continuation of lockdowns compared with the previous years (2017-2019). The surface temperature varies from 26.39 to $33.34^{\circ} \mathrm{C}$ from March 25 to May 15, 2020, during lockdown session (Figs. 5 a and b, 6, 7). During the prior time period (2017-2019) of lockdown state, the variation of surface temperature had been reflected from 26.62 to $36.54^{\circ} \mathrm{C}$ and it must be mentioned that temperature has been reduced by 0.23 to $3.2^{\circ} \mathrm{C}$ within the lockdown ambience (Figs. 5a and b, 6, 7). It is found that the average surface temperature during the mentioned time period is $29.98^{\circ} \mathrm{C}$ in 2020 , while the average value was $31.84^{\circ} \mathrm{C}$ during $2017-2019$. The lower atmospheric temperature gradually rises due to the higher concentration of suspended particulate matters along with other pollutants. So, there is direct relationship between presence of pollutants and increase in lower atmospheric temperature.

\subsection{Evaluation of air quality standard applying statistical techniques}

Two important cluster groups have been created applying hierarchical cluster analysis (HCA) and each cluster has similar air quality standard. The years 2017, 2018 and 2019 are under cluster-1, whereas 2020 is under cluster-2. From the cluster group, it is stated that the air quality is dissimilar in the year 2020 or during lockdown phase than pre-lockdown years (Fig. 8a). The average value of $\mathrm{CO}$ in cluster- 1 is 3.16 , while the value of $\mathrm{CO}$ in 

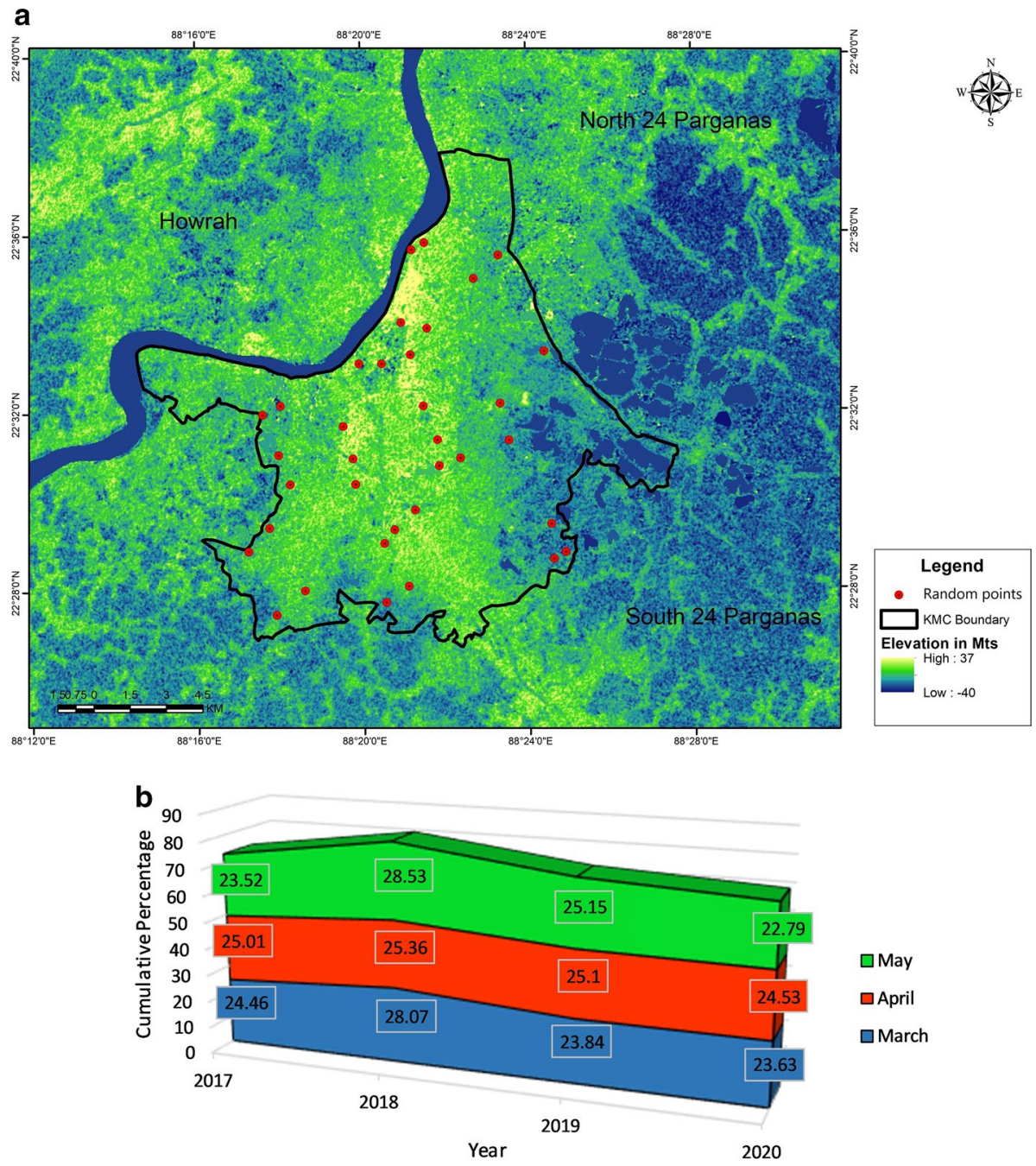

Fig. 5 a Random points for the detection of land surface temperature of Kolkata Metropolitan City (20172020), b the changing percentage of temperature in consecutive 4 years (pre- and during lockdown)

cluster-2 is 0.77 . It has been also noticed that the average value of $\mathrm{NO}_{2}$ and $\mathrm{SO}_{2}$ in cluster- 1 is 25.76 and 14.78, respectively, whereas the values of $\mathrm{NO}_{2}$ and $\mathrm{SO}_{2}$ in cluster-2 are 13.14 and 5.01, respectively. From this overall analysis, it is explained that the air quality is far better in the year 2020 lockdown period with respect to pre-lockdown years (2017, 2018 and 2019). Similarly, principal component analysis (PCA) has been done to find out the relationship and identification of important variables from six different parameters in pre- and during lockdown phase (Fig. 8b i, ii). In pre-lockdown phase, the first two components explain around $65.135 \%$ of the total variables which stand in the ordinal plot. The ordinal plot also reveals that in pre-lockdown phase $\mathrm{O}_{3}, \mathrm{SO}_{2}$ and $\mathrm{NO}_{2}$ have more or less similar pattern, whereas $\mathrm{PM}_{10}, \mathrm{PM}_{2.5}$ and $\mathrm{CO}$ are distantly correlated. On the other hand, during lockdown period the first two components of PCA depict about $81.471 \%$ of the total 


\section{7}

March 2017

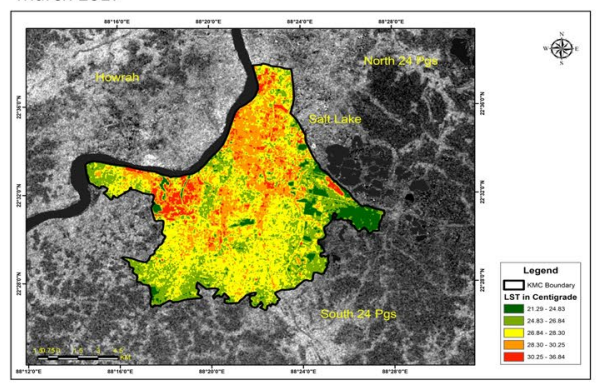

April 2017

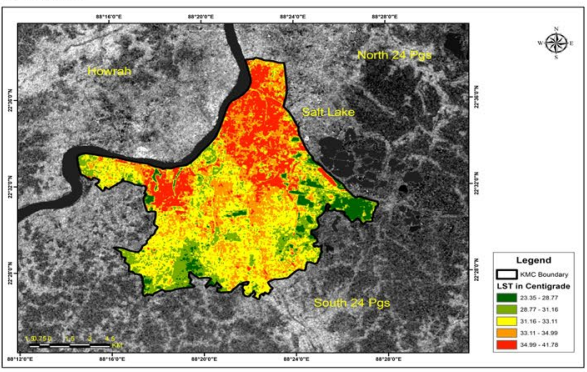

2018

March 2018

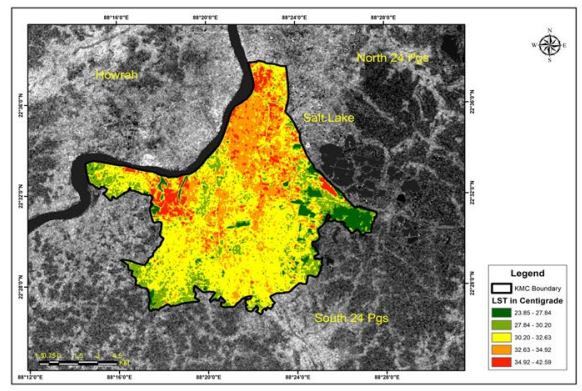

April 2018

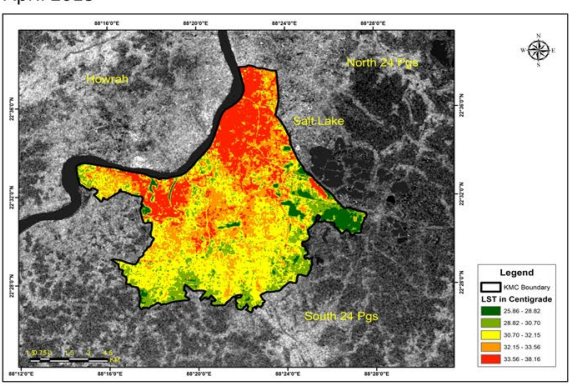

April 2017

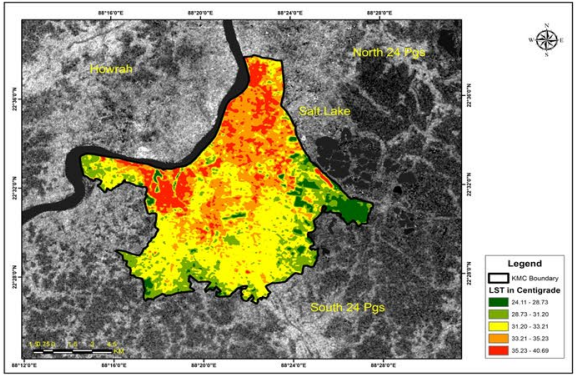

May 2017

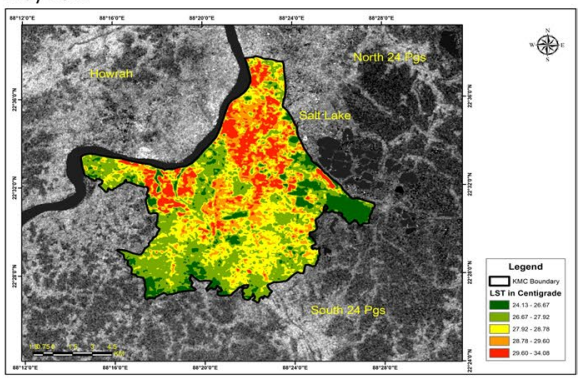

April 2018

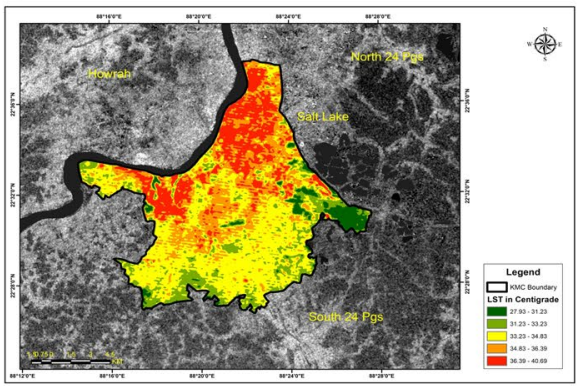

May 2018

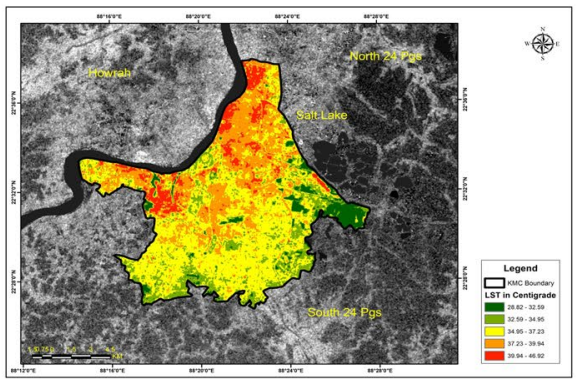

Fig. 6 The variation of land surface temperature (LST) during March 25 to May 15 in 2017 and 2018 


\section{9}

March 2019

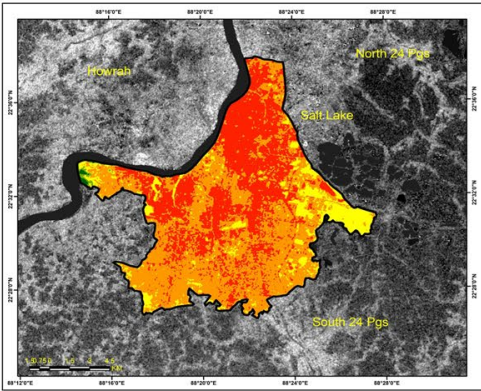

APRIL 2019

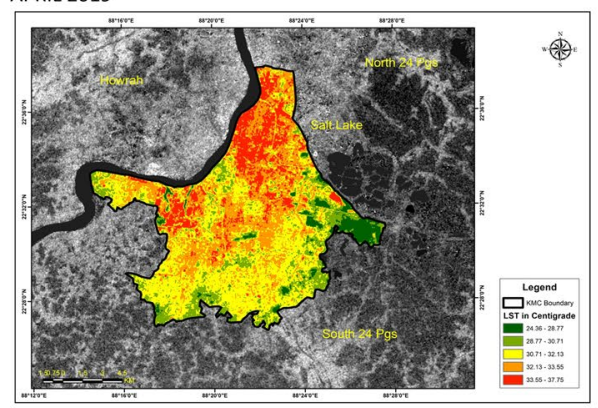

2020

March 2020

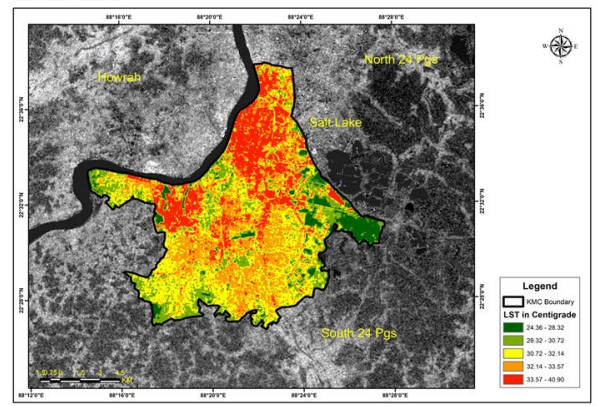

April 2020

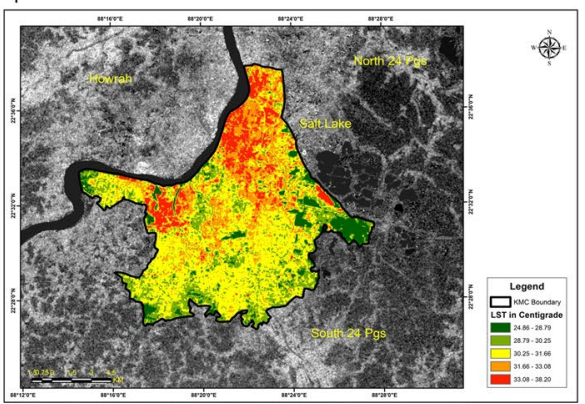

April 2019

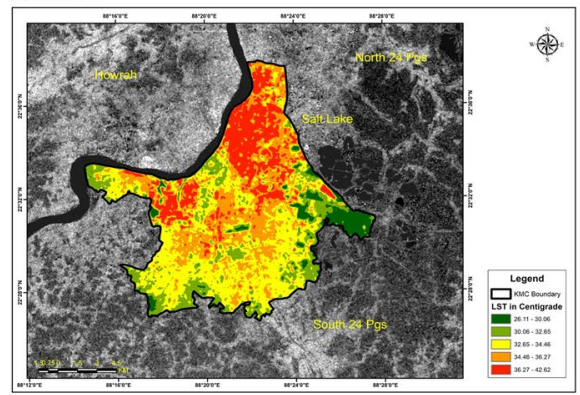

May 2019

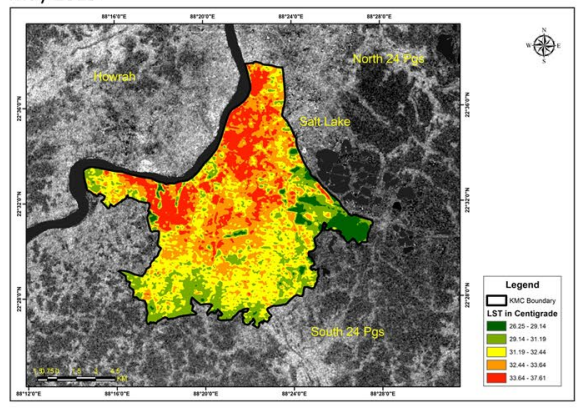

April 2020

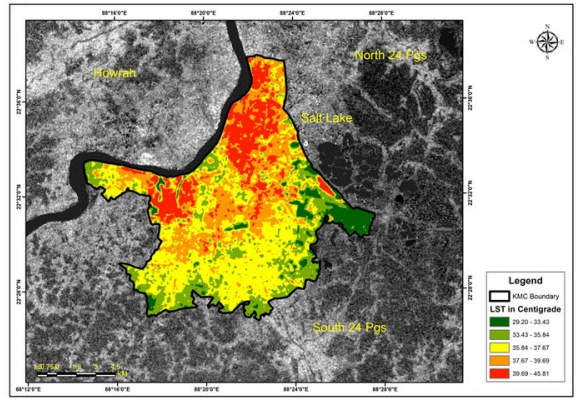

May 2020

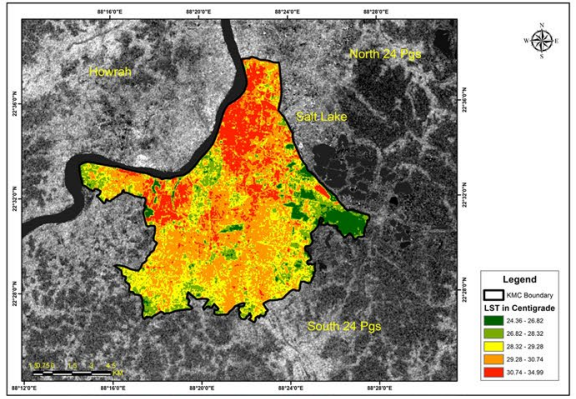

Fig. 7 The variation of land surface temperature (LST) during March 25 to May 15 in 2019 and 2020 

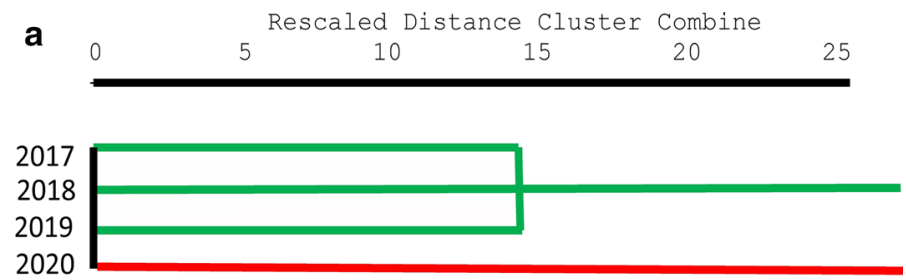

2020

b

Cluster 1

Cluster 2

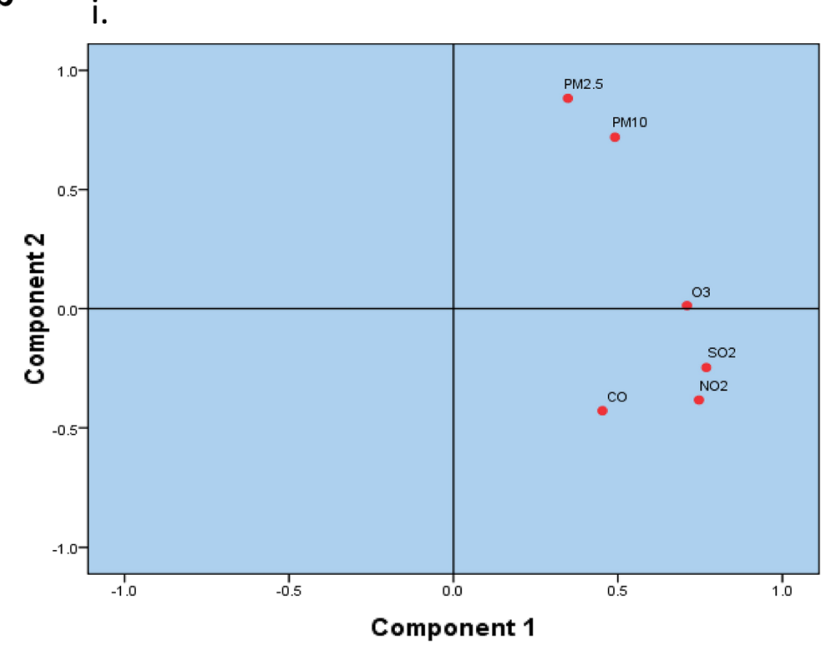

ii.

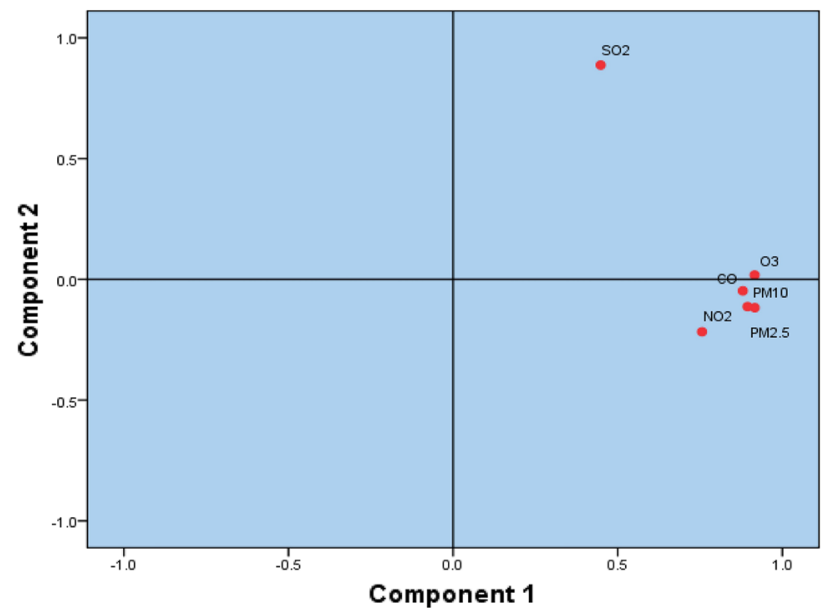

Fig. 8 a Dendrogram portrays the variation of yearly concentration of air pollutants during and pre lockdown phase based on Hierarchical Cluster Analysis (HCA), b $i$ Interaction and relationship among the air pollutants analysed by PCA in the year 2019, ii interaction and relationship among the air pollutants analysed by PCA in the year 2020 
variables and the ordinal plot also reveals that $\mathrm{SO}_{2}$ has a distant correlation with other parameters, while other parameters have a same pattern.

\section{Discussion}

As the air quality is deteriorating day by day across the globe, the longevity of human life compels to turn down and annual death toll is ever-increasing throughout the world within the last decade. Around $8 \%$ human demise had been caused due to the threat of air pollution mostly in the countries in Asia, Africa and a small portion of Europe (WHO 2016). The global human deaths are directly linked with respiratory diseases (26\%), chronic obstructive pulmonary disease (25\%), stroke and ischaemic heart (17\%) due to the threat of severe air pollution (WHO 2020b). According to the United Nations Environment Programme, 1.1 billion world populations have been compelled to inhale toxic air (UNEP 2002). It must be predicted that the proportion of respiratory and allergic illness would be augmented mostly because of the rapid modification of air quality in different corners of the globe (Haque and Singh 2017). In general, lighting, power plants and transport sectors are the principal source areas of $\mathrm{NO}_{2}$ (He et al. 2020; Sharma et al. 2020). Several studies have pointed out that long-time acquaintance to $\mathrm{NO}_{2}$ is responsible for various deadly diseases like lung function disorders, stroke, cardiovascular disease, severe asthma, untimely demise, etc. (Saeha et al. 2020; Humbal et al. 2019; Arden Pope et al. 2004). Not only the long-time based contact, short-spell contact with $\mathrm{NO}_{2}$ can also aggravate the death rate of human being (Faustini et al. 2014). The gaseous emissions from the chimneys of power plants and industries, vehicles, burning of biomass, solid waste and dust particles from constructional activities are the principal anthropogenic sources of air pollution including $\mathrm{CO}, \mathrm{NO}_{2}, \mathrm{SO}_{2}$, suspended particulate matters $\left(\mathrm{PM}_{10}, \mathrm{PM}_{2.5}\right)$ in India. In the last two decades, the increasing trend of morbidity as well as mortality due to cardiovascular disease, chronic obstructive pulmonary disease, infections, asthma, bronchitis is regarded as the fatal consequences of tremendous air pollution in city and town areas countrywide.

The previous study highlighted that approximately $70 \%$ people of Kolkata have been victimized due to the respiratory illness caused by the lower atmospheric toxic pollutants (Mukhopadhyay 2009). Here, the study reflects that enormous accumulation of vital air pollutants like $\mathrm{CO}, \mathrm{NO}_{2}, \mathrm{SO}_{2}, \mathrm{PM}_{10}, \mathrm{PM}_{2.5}$ in the lower atmosphere degrades the air quality of Kolkata over the years. It must be stated that the gaseous and dust emissions from outdated and unwell-maintained vehicles, numerous industries, activities of eateries and construction works are continuously degrading the air quality standard in and around the city. Among these sources, transport sector plays a crucial role to excess release of $\mathrm{NO}_{2}$, whereas maximum $\mathrm{CO}$ and $\mathrm{SO}_{2}$ have been emitted from different modes of transport and large, medium and small-scale industries in and around the vicinity of Kolkata. Moreover, $\mathrm{PM}_{10}$ and $\mathrm{PM}_{2.5}$ have been mostly released from road dust, gaseous emission of vehicles, industrial chimneys and combustion of coal and burning of municipal wastes. Presently, as the country is passing through the lockdown system (strictly impose the quarantine norms upon the citizens), the industrial activities as well as transport modes are absolutely paused. Roadways, railways, airways and waterways are mostly stopped during the lockdown period which reduces the concentration of $\mathrm{CO}$ and $\mathrm{NO}_{2}$ in the atmosphere of Kolkata. Moreover, partially shutdown of industrial and transport sectors reduces $\mathrm{SO}_{2}$ level than the preceding period of lockdown but due to continuous coal combustion in different thermal power stations (Kolaghat, Bandel and Budge-Budge thermal power stations) at 
the vicinity of Kolkata, $\mathrm{SO}_{2}$ level has not been significantly declined. The $\mathrm{PM}_{10}$ and $\mathrm{PM}_{2.5}$ have been drastically fallen due to diminution of fossil fuel combustion, transportation and industrial release of dusts along with closed constructional activities in the city. It is noteworthy in this context that the concentration of $\mathrm{O}_{3}$ is one of the important parameters for assessing air quality and it is comprehensively improved during lockdown because of the falling of $\mathrm{NO}_{2}$ accumulation. During the lockdown phase, the concentration of $\mathrm{O}_{3}$ amplifies in the lower atmosphere due to low consumption of $\mathrm{O}_{3}$ and consequently leading to less emission of $\mathrm{NO}_{2}$ from the anthropogenic sources (Andrade et al. 2017; Tobias et al. 2020). The natural quantity of ozone in the troposphere is normally around 0.04 parts per million (ppm), and that amount is not dangerous to human health. The concentration of ozone above $200 \mu \mathrm{g} / \mathrm{m}^{3}$ or $0.2 \mathrm{mg} / \mathrm{m}^{3}$ or $0.1 \mathrm{ppm}$ in the lower troposphere is very harmful for the human health or environment but during lockdown phase specially in the months of March $\left(53.48 \mu \mathrm{g} / \mathrm{m}^{3}\right)$, April $\left(45.56 \mu \mathrm{g} / \mathrm{m}^{3}\right)$ and May $\left(38.68 \mu \mathrm{g} / \mathrm{m}^{3}\right)$ the average concentration of ozone is slightly increased compared with the previous year due to less emission of $\mathrm{NO}_{2}$ from the anthropogenic sources, although the average concentration level of ozone during lockdown phase is not detrimental for environment including human health.

The land surface temperature is slightly dropped during the lockdown period (2020) due to short duration lockdown along with controlled economic activities. In general, various natural as well as anthropogenic activities regulate land surface temperature on the surface of the earth, whereas long-term sustainable environmental management steps can partially modify the spatio-temporal weather conditions. In those stations which are located at the vicinity of greeneries, the air pollution rate is comparatively lower with respect to other stations. It is highly significant that the extension of lockdown period due to COVID19 pandemic incredibly affects the economic supply chain, socio-cultural rhythm of the nations and mental health of the people worldwide. But it is notable that the natural environment becomes competent to restore its balance through homeostatic mechanism due to the temporary shut-down of industrial, commercial and transportation activities.

\section{Post-lockdown sustainable environmental management plan}

From environmental perspective, the lockdown system is very healthy. The declining trend of air pollution level in Kolkata during lockdown is a momentary phenomenon. The enforcement of lockdown system is not a permanent remedial measure to mitigate the menace of pollution. So, an alternative sustainable management technique should be implemented to keep the purity of environment. It must be noted that plants are the principal recipient of different types of air pollutants and act as an enormous sink (Kaur and Nagpal 2017; Letter and Jager 2020). A scientific study has been identified some plant species along with high absorption capacity of specific pollutants (Salih et al. 2017; Table 3). Suspended particulate matters and dust particles are absorbed through the stomatal pores into the leaf or over the surface of the leaf (Farmer 2002). The air pollution-tolerant species plantation in urban vacant spaces would play an effective role to ameliorate environmental health along with quality of urban life (Bamniya et al. 2011). The air pollution tolerance index (APTI) is applied to assess the susceptibility or resistance level of plant species for air pollutants (Pandey et al. 2015). The improvement of green envelop by plantation of tolerant species can combat air pollution to a certain level. The selection of plant species (based on tolerance level) is a principal factor for the mitigation of urban air pollution. Subsequently, APTI is used to select tolerant plant 
Table 3 Name of high air pollution-tolerant plant species along with major absorbed pollutants for tropical and sub-tropical regions

\begin{tabular}{llll}
\hline Sl. no & $\begin{array}{l}\text { Scientific names of tolerant } \\
\text { plants }\end{array}$ & $\begin{array}{l}\text { Common name of tolerant } \\
\text { plants }\end{array}$ & $\begin{array}{l}\text { Major pollutants absorbed by } \\
\text { the plants }\end{array}$ \\
\hline 1 & Ficus bengalensis & Banyan & $\mathrm{CO}, \mathrm{NO}_{2}, \mathrm{SO}_{2}, \mathrm{PM}_{2.5}, \mathrm{PM}_{10}$ \\
2 & Psidium guajava & Guava & $\mathrm{SO}_{2}, \mathrm{PM}_{2.5}, \mathrm{PM}_{10}$ \\
3 & Mangifera indica & Mango & $\mathrm{CO}_{2}, \mathrm{NO}_{2}, \mathrm{SO}_{2}, \mathrm{PM}_{2.5}, \mathrm{PM}_{10}$ \\
4 & Hibiscus rosa-sinensis & China rose & $\mathrm{PM}_{10}, \mathrm{PM}_{2.5}, \mathrm{SO}_{2}$ \\
5 & Bougainvillea spectabilis & Bougainvillea & $\mathrm{PM}_{2.5}, \mathrm{PM}_{10}, \mathrm{NO}_{2}, \mathrm{SO}_{2}, \mathrm{CO}$ \\
6 & Neolamarkia cadamba & Kadam/ Burflower tree & $\mathrm{CO}, \mathrm{NO}_{2}, \mathrm{SO}_{2}, \mathrm{PM}_{2.5}, \mathrm{PM}_{10}$ \\
7 & Ficus religiosa & Peepul & $\mathrm{CO}, \mathrm{NO}_{2}, \mathrm{SO}_{2}, \mathrm{PM}_{2.5}, \mathrm{PM}_{10}$ \\
8 & Cascabela thevetia & Yellow oleander & $\mathrm{NO}_{2}, \mathrm{SO}_{2}, \mathrm{PM}_{2.5}, \mathrm{PM}_{10}$ \\
9 & Cassia siamea & Cassod tree & $\mathrm{SO}_{2}, \mathrm{NO}_{2}, \mathrm{CO}$ \\
10 & Ricinus communis & Castor oil plant & $\mathrm{CO}, \mathrm{NO}_{2}$ \\
11 & Eucalyptus globus & Southern blue gum & $\mathrm{CO}_{2}, \mathrm{NO}_{2}, \mathrm{SO}_{2}, \mathrm{PM}_{2.5}, \mathrm{PM}_{10}$ \\
12 & Azadirachta indica & Neem & $\mathrm{CO}, \mathrm{SO}_{2}, \mathrm{PM}_{2.5}, \mathrm{PM}_{10}, \mathrm{NO}_{2}$ \\
\hline
\end{tabular}

species particularly for the reduction of vehicular pollution in urban environment (Kaur and Nagpal 2017). Cascabela Thevetia, Mangifera Indica, Cassia Siamea and Neolamarkia Cadamba and Azadirachta indica have been recognized as the most tolerant species according to their APTI value and recommended to plant along sides of the busy roads of tropical and subtropical areas. Beside this, Ficus Bengalensis, Ricinus Communis, Cassia Siamea, Ficus Religiosa, Bougainvillea Spectabilis have been identified as intermediate tolerant (high pollutants absorption capacity) species scattered along the National Highway-5 across Bhubaneswar in Odisha, India (Acharya et al. 2017). Moreover, a scientific study highlighted that Eucalyptus Globus has the extreme tolerance capacity against air pollution followed by Ficus Religiosa and Mangifera Indica and those species have reduced air pollution across the heavy traffic areas in Dehradun, India (Lohe et al. 2015). It is also proved that Ficus Religiosa has the maximum capacity of tolerance in terms of air pollution (Muhammad et al. 2016). Another study revealed that Hibiscus rosa-sinensis followed by Psidium guajava, Mangifera indica and Ficus bengalensis have achieved the maximum APTI value in case of industrial area of Rourkela in Odisha, India (Rai et al. 2013). The geographical distribution of vegetation cover in the city of Kolkata helps to comprehend the overall spatial association along with the density of plant species (Fig. 9). It must be stated that the physical conditions of Kolkata are exceedingly favourable for the growth of these above-mentioned plants and these plant species can place in the vacant spaces (Fort William, Hastings, Victoria Memorial, Maidan, Vidhan Sabha Area, Eden Garden Surroundings, Governors House, Tollygunge Golf Club Area, Golf Garden Area, Rabindra Sarovar Area, Jodhpur, Park, East Kolkata Wetlands Area, Salt Lake Area, etc.) of the city and road sides. This plant association would undoubtedly modify the air quality standard for long-term basis (Table 3). But the matter of serious concern is that proportion of vacant space is very much limited in this highly populous city and the city is extremely congested with high-rise buildings along with busiest roadways. In this context, the implementation of sustainable micro-green belt project like roof garden, green frontage or green wall, vertical green zone, roadside garden should be encouraged to re-establish 
Table 4 High air pollutiontolerant climber plant species in tropical and sub-tropical regions
The most tolerant climber plant species

\begin{tabular}{lll}
\hline Sl. no & Scientific names of plants & Common name of plants \\
\hline 1 & Ipomoea palmata & Railroad creeper \\
2 & Aristolochia elegans & Calico flower \\
3 & Thunbergia grandiflora & Bengal clockvine \\
4 & Quisqualis indica Linn & Rangoon creeper \\
5 & Clerodendrum splendens G. Don & Glory tree \\
6 & Petria volubilis Linn & Purple wreath \\
7 & Antigonon leptopus Hook & Coral vine \\
\hline
\end{tabular}

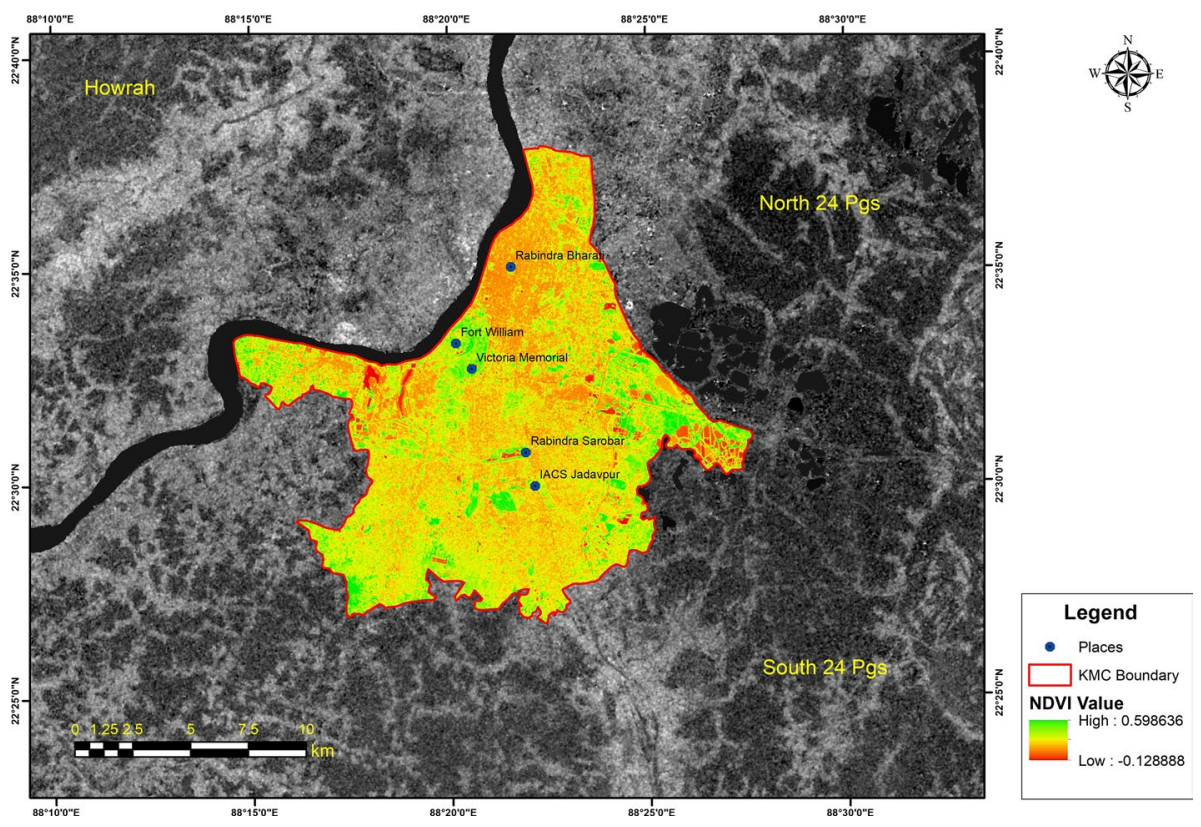

Fig. 9 Spatial distribution of vegetal cover in Kolkata (according to NDVI values)

the greenish coverage all over Kolkata. Few climber plants namely Ipomoea palmata, Aristolochia elegans, Thunbergia grandiflora, Quisqualisindica Linn., Clerodendrumsplendens G. Don., Petriavolubilis Linn., Antigononleptopus hook have been selected as ideal for vertical greenery system (VGS) in terms of their high APTI value in the tropical urban area of Varanasi in Uttar Pradesh, India (Pandey et al. 2015). Kolkata is considered as an ideal habitat for these climber plants also due to its parallel climatic conditions. These species can be kept on the roof top, balcony and wall, grill of every household, industrial and commercial centre, shopping complex, etc. and to restore the natural environmental quality of Kolkata (Table 4). So, the development of green sphere as well as proper execution of reforestation and afforestation scheme throughout the city is utmost important steps to recover the sustainable urban ecological indicators after the temporary lockdown. 


\section{Conclusions}

The lockdown strategy due to COVID-19 pandemic disaster offers a meaningful message to all the countries worldwide for restoring the environmental quality as well as natural ecosystem stability. Apparently, the slaughterer COVID-19 pandemic and constant lockdown becomes a curse towards the millions of people and the world economy confronts a massive disruption due to the unpleasant and unusual incident. In the interim, the purification of environment along with air quality modification has become certainly the precious gifts of temporary lockdown system during global emergency. In Kolkata, the upgrading of air quality standard and declining trend of surface temperature definitely bring the healthy environment during lockdown period. The severe air pollution is the principal regulating factor for high rate COVID-19 infection and mortality in the City Kolkata. This study revealed that the concentration of pollutants like $\mathrm{NO}_{2}, \mathrm{CO}, \mathrm{PM}_{10}$ and $\mathrm{PM}_{2.5}$ over the City of Kolkata during lockdown phase was significantly low compared with previous years. This scientific study has tried to give some long-term remedial measures for the improvement of the health of the environment of Kolkata. The applied research with instrumental and methodological development is highly required to combat such harmful air pollution in the different polluted cities of India. All State Governments along with Central Government of India should incorporate different relevant aspects of environment as mandatory in academic syllabus and provide funds to young scholars and scientists for such applied research. In spite of few good researches, there is a big gap between scientists and policymakers regarding the implementation of research findings. In this context, administrators and policymakers should consider and implement such high-quality research findings to ameliorate the air quality standards of various polluted cities of India. The deadly COVID-19 pandemic offers an enormous likelihood basically for scientists to revitalize health of the total environment. Ultimately, the lockdown system retrieves the sparkle of environment by means of improving air quality standards all over the city where the urban ecological forms and processes have been degraded due to unjustifiable modern livelihood along with fast economic progression. Lockdown system would be the best practice today for all the modern industrial countries in the world and it will be the best therapy to reduce all types of environmental pollution as well as degradation. Simultaneously, the developed nations should build sustainable indigenous models for the cohabitation among environment, society and development. It must be opined that partial lockdown would be beneficial for the health of the total environment and especially for populous City Kolkata (India). Thus, the temporary lockdown mechanism should be treated as the environmental blessings instead of the ruthless curse globally.

Acknowledgements The authors would like to acknowledge the European Space agency (ESA), USA and National Aeronautics and Space Administration (NASA). Simultaneously, the authors are also grateful to the State Pollution Control Board, Govt. of West Bengal, India, for providing necessary data related with air quality changes of Kolkata during the lockdown period and previous years.

\section{Compliance with ethical standards}

Conflicts of interest The authors declare that they have no conflict of interest. 


\section{References}

Acharya, S., Jena, R.C., Das, S.J., Pradhan, C., Chand, P.K. (2017) Assessment of air pollution tolerance index of some selected roadside plants of Bhubaneswar city of Odisha State in India. Journal of Environmental Biology, 38, 1397-1403. https://doi.org/10.22438/jeb/38/6/MS-183.

Andrade, M. F., Kumar, P., Freitas, E. D., Ynoue, R. Y., Martins, J., Martins, L. D., et al. (2017). Air quality in the megacity of São Paulo: evolution over the last 30 years and future perspectives. Atmospheric Environment, 159, 66-82. https://doi.org/10.1016/j.atmosenv.2017.03.051.

Arden Pope, C., Burnett Richard, T., Thurston George, D., Thun Michael, J., Calle Eugenia, E., et al. (2004). Cardiovascular mortality and long-term exposure to particulate air pollution. Circulation, 109, 71-77. https://doi.org/10.1161/01.cir.0000108927.80044.7f.

Bamniya, B. R., Kapoor, C. S., Kapoor, K., \& Kapasya, V. (2011). Harmful effect of air pollution on physiological activities of Pongamia pinnata(L.) Pierre. Clean Technologies and Environmental Policy, 14, 115-124. https://doi.org/10.1007/s10098-011-0383-z.

Bashir, M. F., Ma, B., Komal, B., Bashir, M. A., Tan, D., \& Bashir, M. (2020). Correlation between climate indicators and COVID-19 pandemic in New York, USA. Science of the Total Environment, 728, 138835. https://doi.org/10.1016/j.scitotenv.2020.138835.

Bherwani, H., Gupta, A., Anjum, S., Anshul, A., Kumar, R. (2020). Exploring Dependence of COVID-19 on environmental factors and spread prediction in India. Research Square. https://doi.org/10.21203/ rs.3.rs-25644/v1.

CAMS (2020) CAMS， 2020. https://atmosphere.copernicus.eu/amid-coronavirus-outbreak-copernicus -monitors-reduction-particulate-matter-pm25-over-china.

Census of India, Govt. of India. (2011). Provisional Population Totals. Registrar General \& Census Commissioner. https://censusindia.gov.in/2011-prov-results/prov_results_paper1_india.html.

Chakraborty, I., \& Maity, P. (2020). COVID-19 outbreak: Migration, effects on society, global environment and prevention. Science of the Total Environment, 728, 1-7. https://doi.org/10.1016/j.scito tenv.2020.138882.

Chen, H., Guo, J., Wang, C., Luo, F., Yu, X., Zhang, W., et al. (2020). Clinical characteristics and intrauterine vertical transmission potential of COVID19 infection in nine pregnant women: a retrospective review of medical records. Lancet, 20, 30360-30363. https://doi.org/10.1016/S0140-6736(20)30360-3.

Coronavirus in India. (2020). https://www.covid19india.org/.

CPCB. (2009). Comprehensive industry document stone crushers, Central Pollution Control Board, Govt. of India, Series: COINDS/78/2007-08, 1.1-8.21. https://cpcbenvis.nic.in/scanned\%2520reports/COMP_ IND_STONE_CRUSHER_REPORT.pdf.

CPCB. (2020). Impact of lockdown (25th March to 15th April) on air quality. Ministry of Environment, Forest and Climate Change, Govt. of India, Delhi, 1-62. https://cpcb.nic.in/latest-cpcb.php.

Das, R., Khezri, B., Srivastava, B., Datta, S., Sikdar, P. K., Webster, R. D., et al. (2015). Trace element composition of PM2.5 and PM10 from Kolkata-a heavily polluted Indian metropolis. Atmospheric Pollution Research, 6, 742-750. https://doi.org/10.5094/APR.2015.083.

Dutheil, F., Baker, S. J., Navel, V. (2020). COVID-19 as a factor influencing air pollution?. Environmental Pollution. https://doi.org/10.1016/j.envpol.2020.114466

Eroglu, H. (2020). Effects of Covid-19 outbreak on environment and renewable energy sector. Environment, Development and Sustainability. . https://doi.org/10.1007/s10668-020-00837-4.

ESA (2020a) ESA, 2020. https://www.esa.int/Applications/Observing_the_Earth/Copernicus/Sentinel-5P/ Air_pollution_drops_in_India_following_lockdown.

ESA (2020b) ESA, 2020. https://www.esa.int/Applications/Observing_the_Earth/Copernicus/Sentinel-5P/ Coronavirus_lockdown_leading_to_drop_in_pollution_across_Europe.

ESA (2020c) ESA, 2020. https://www.esa.int/Applications/Observing_the_Earth/Copernicus/Sentinel-5P/ COVID-19_nitrogen_dioxide_over_China.

Farmer, A. (2002). Effects of particulates. In: Bell, J.N.B., Treshow, M. (eds), Air pollution and plant life, 2nd edn. West Sussex: Wiley, pp. 187-199. https://www.wiley.com/en-us/Air+Pollution+and+Plant +Life\%2C+2nd+Edition-p-9780471490913.

Faustini, A., Rapp, R., \& Forastiere, F. (2014). Nitrogen dioxide and mortality: review and meta-analysis of long-term studies. European Respiration Journal, 44, 744-753. https://doi.org/10.1183/09031 936.00114713.

Gautam, S. (2020a). COVID-19: air pollution remains low as people stay at home. Air Quality Atmosphere Health. . https://doi.org/10.1007/s11869-020-00842-6.

Gautam, S. (2020). The influence of COVID-19 on air quality in India: a boon or inutile. Bulletin of Environmental Contamination and Toxicology, 104(6), 724-726. https://doi.org/10.1007/s00128-02002877-y. 
Gautam, S., \& Hens, L. (2020). SARS-CoV-2 pandemic in India: what might we expect? Environment Development and Sustainability, 22, 3867-3869. https://doi.org/10.1007/s10668-020-00739-5.

Gautam, S., \& Trivedi, U. K. (2020). Global implications of bio-aerosol in pandemic. Environment Development and Sustainability, 22, 3861-3865. https://doi.org/10.1007/s10668-020-00704-2.

Global Carbon Project (2020) Global Carbon Project, 2020. https://www.globalcarbonproject.org/carbo nbudget/index.htm.

Haque, M. S., \& Singh, R. B. (2017). Air pollution and human health in Kolkata, India: a case study. Climate, 5, 1-16. https://doi.org/10.3390/cli5040077.

Health and Family Welfare Department. (2020). West Bengal COVID-19 Health Bulletin-15th May 2020. Govt. of West Bengal. https://www.wbhealth.gov.in/pages/corona/bulletin.

He, M. Z., Kinney, P. L., Li, T., Chen, C., Sun, Q., Ban, J., et al. (2020). Short- and intermediate-term exposure to NO2 and mortality: a multi-county analysis in China. Environmental Pollution, 261, 114165. https://doi.org/10.1016/j.envpol.2020.114165.

Huang, C., Wang, Y., Li, X., Ren, L., Zhao, J., Hu, Y., et al. (2020). Clinical features of patients infected with 2019 novel coronavirus in Wuhan, China. Lancet, 395, 497-506. https://doi.org/10.1016/ S0140-6736(20)30183-5.

Huang, X., Ding, A., Gao, J., Zheng, B., Zhou, D., Qi, X., et al. (2020). Enhanced secondary pollution offset reduction of primary emissions during COVID-19 lockdown in China. EarthArXiv. https:// doi.org/10.31223/osf.io/hvuzy.

Humbal, C., Gautam, S., \& Trivedi, U. K. (2018). A review on recent progress in observations, and health effects of bioaerosols. Environment International, 118, 189-193. https://doi.org/10.1016/j. envint.2018.05.053.

Humbal, C., Gautam, S., et al. (2019). Evaluating the colonization and distribution of fungal and bacterial bioaerosol in Rajkot, western India using multi-proxy approach. Air Quality, Atmosphere and Health, 12(6), 693-704. https://doi.org/10.1007/s11869-019-00689-6.

Humbal, C., Gautam, S., Joshi, S. K., Rajput, M. S. (2020). Spatial variation of airborne allergenic fungal spores in the ambient PM2.5-a study in Rajkot City, Western Part of India. In: Gupta, et al. (ed), Measurement, analysis and remediation of environmental pollutants. Singapore: Springer, pp. 199-209. https://doi.org/10.1007/978-981-15-0540-9.

Jribi, S., Ismai, H.B., Doggui, D., Debbabi, K. (2020). COVID-19 virus outbreak lockdown: What impacts on household food wastage? Environment, Development and Sustainability, 22, 39393955. https://doi.org/10.1007/s10668-020-00740-y

Kaur, M., \& Nagpal, A. K. (2017). Evaluation of air pollution tolerance index and anticipated performance index of plants and their application in development of green space along the urban areas. Environmental Science and Pollution Research, 24, 18881-18895. https://doi.org/10.1007/s1135 6-017-9500-9.

Kerimray, A., Baimatova, N., Ibragimova, O. P., Bukenov, B., Kenessov, B., Plotitsyn, P., et al. (2020). Assessing air quality changes in large cities during COVID-19 lockdowns: the impacts of trafficfree urban conditions in Almaty, Kazakhstan. Science of the Total Environment, 730, 1-8. https:// doi.org/10.1016/j.scitotenv.2020.139179.

Kumar, B., \& Singh, R. B. (2003). Urban development and anthropogenic climate change: experience in Indian metropolitan cities. Ltd, New Delhi, India: Manak Publication Pvt.

Landsat Project Science Office. (2002). Landsat 7 Science Data User's Handbook. Goddard Space Flight Center, NASA, Washington, DC. https://ltpwww.gsfc.nasa.gov/IAS/hand-book/handbook_toc.html.

Lau, H., Khosrawipour, V., Kocbach, P., Mikolajczyk, A., Schubert, J., Bania, J., et al. (2020). The positive impact of lockdown in Wuhan on containing the COVID-19 outbreak in China. Journal of Travel Medicine, 37, 1-14. https://doi.org/10.1093/jtm/taaa037.

Li, L., Li, Q., Huang, L., Wang, Q., Zhu, A., Xu, J., et al. (2020). Air quality changes during the COVID19 lockdown over the Yangtze River Delta Region: an insight into the impact of human activity pattern changes on air pollution variation. Science of the Total Environment, 732, 1-11. https://doi. org/10.1016/j.scitotenv.2020.139282.

Lohe, R. N., Tyagi, B., Singh, V., Tyagi, P. K., Khanna, D. R., \& Bhutiani, R. (2015). A comparative study for air pollution tolerance index of some terrestrial plant species. Global Journal of Environmental Science and Management, 1, 315-324. https://doi.org/10.7508/gjesm.2015.04.006.

Mate, A., Killian, J. A., Wilder, B., Charpignon, M., Awasthi, A., Tambe, M., et al. (2020). Evaluating COVID-19 Lockdown Policies for India: a Preliminary Modeling Assessment for Individual States. SSRN, 3575207. https://doi.org/10.2139/ssrn.3575207.

Mitra, A., Chaudhuri, T.R., Mitra, A., Pramanick, P., Zaman, S., Mitra, A., Chaudhuri, T.R., Mitra, A., Pramanick, P., Zaman, S. (2020). Impact of COVID-19 related shutdown on atmospheric carbon dioxide level in the city of Kolkata. Science and Education, 6, 84-92. https://sites.google.com/site/pjsciencea. 
Muhmmad, S., Long, X., \& Salman, M. (2020). COVID-19 pandemic and environmental pollution: a blessing in disguise? Science of the Total Environment, 728, 1-5. https://doi.org/10.1016/j.scito tenv.2020.138820.

Muhammad, S., Shakeel, F., Khan, Z., Hasnain, M., Cheema, T.A. (2016). Assessment of air pollution sensitivity of some selected tree species of busiest roads of Lahore city. Journal of Biology and Environmental Science, 9, 99-105. https://www.innspub.net/.

Mukhopadhyay, K. (2009). Air Pollution in India and Its Impact on the Health of Different Income Groups. New York: Nova Science Publishers.

NASA. (2020a). NASA, 2020. https://doi.org/10.1016/j.envpol.2020.114280.

NASA. (2020b). NASA, 2020. https://earthsky.org/earth/satellite-images-air-pollution-india-covid19.

Pandey, A. K., Pandey, M., \& Tripathi, B. D. (2015). Assessment of Air Pollution Tolerance Index of some plants to develop vertical gardens near street canyons of a polluted tropical city. Ecotoxicology and Environmental Safety. https://doi.org/10.1016/j.ecoenv.2015.08.028.

Rai, P.K., Panda, L.L.S., Chutia, B.M., Singh, M.M. (2013). Comparative assessment of air pollution tolerance index (APTI) in the industrial (Rourkela) and non industrial area (Aizawl) of India: an ecomanagement approach. African Journal of Environmental Science and Technology, 7, 944-948. https:// www.academicjournals.org/AJEST.

Saeha, S., Bai, L., et al. (2020). Association between road traffic noise and incidence of diabetes mellitus and hypertension in Toronto, Canada: a population-based cohort study. Journal of American Heart Association, 9, 013021. https://doi.org/10.1161/JAHA.119.013021.

Sarkodie, S. A., \& Owusu, P. A. (2020). Global assessment of environment, health and economic impact of the novel coronavirus (COVID-19). Environment, Development and Sustainability.. https://doi. org/10.1007/s10668-020-00801-2.

Sharma, S., Zhang, M., Gao, J., Zhang, H., \& Kota, S. H. (2020). Effect of restricted emissions during COVID-19 on air quality in India. Science of the Total Environment, 728, 1-8. https://doi. org/10.1016/j.scitotenv.2020.138878.

Sobrino, J. A., \& Raissouni, N. (2000). Toward remote sensing methods for land cover dynamic monitoring: application to Morocco. International Journal of Remote Sensing, 21, 353-366. https://doi. org/10.1080/014311600210876.

Tian, H., Liu, Y., Li, Y., Wu, C.-H., Chen, B., Kraemer, M.U.G., et al. (2020). An investigation of transmission control measures during the first 50 days of the COVID-19 epidemic in China. Science. https:// doi.org/10.1126/science.abb6105.

Tobías, A., Carnerero, C., Reche, C., Massagué, J., Via, M., Minguillón, M. C., et al. (2020). Changes in air quality during the lockdown in Barcelona (Spain) one month into the SARS-CoV-2 epidemic. Science of the Total Environment, 726, 1-4. https://doi.org/10.1016/j.scitotenv.2020.138540.

Tosepu, R., Gunawan, J., Effendy, S. D., Ahmad, A. I., Lestari, H., Bahar, H., et al. (2020). Correlation between weather and Covid-19 pandemic in Jakarta. Indonesia. Sci Total Environ, 725, 138436. https ://doi.org/10.1016/j.scitotenv.2020.138436.

UNEP. (2002). Environmental Threats to Children: Children in the New Millennium. United Nations Environmental Programme, UNICEF, WHO. https://www.who.int/water_sanitation_health/hygiene/setti ngs/ChildrenNM7.pdf?ua=1

Wang, C., Horby, P. W., Hayden, F. G., \& Gao, G. F. (2020). A novel coronavirus outbreak of global health concern. Lancet, 395, 470-473. https://doi.org/10.1016/s0140-6736.

Wang, P., Chen, K., Zhu, S., Wang, P., \& Zhang, H. (2020). Severe air pollution events not avoided by reduced anthropogenic activities during COVID-19 outbreak. Resources, Conservation and Recycling, 158, 104814. https://doi.org/10.1016/j.resconrec.2020.104814.

Wee, S.L., McNeil Jr., D.G., Hernandez, J.C. (2020). W.H.O declares global emergency as Wuhan coronavirus spreads. The New York times. https://www.nytimes.com/2020/01/30/health/coronavirus-world -health-organization.html.

West Bengal Pollution Control Board. (2020). Air quality information system. Govt. of West Bengal. https:// emis.wbpcb.gov.in/airquality/JSP/aq/districtwiseReport.jsp.

Wilder-Smith, A., \& Freedman, D. O. (2020). Isolation, quarantine, social distancing and community containment: pivotal role for old-style public health measures in the novel coronavirus $(2019-\mathrm{nCoV})$ outbreak. J Travel Med. https://doi.org/10.1093/jtm/taaa020.

WHO. (2006). WHO Air Quality Guidelines for Particulate Matter, Ozone, Nitrogen Dioxide and Sulfur Dioxide: Global Update 2005: Summary of Risk Assessment. https://apps.who.int/iris/handle/10665 169477.

WHO. (2011). Urban outdoor air pollution database. https:/www.who.int/phe/health_topics/outdoorair/ databases/cities-2011/en/.

WHO (2016) WHO, 2016. https://www.who.int/health-topics/air-pollution\#tab=tab_1. 
WHO. (2020a). Coronavirus disease (COVID-19) pandemic. https://www.who.int/emergencies/diseases/ novel-coronavirus-2019.

WHO. (2020b.) Coronavirus Disease 2019 (COVID-19) Situation Report - 36. https://www.who.int/docs/ default-source/coronaviruse/situation-reports/20200225-sitrep-36-covid-19.pdf?sfvrsn=2791b4e0_2.

WHO. (2020c). Statement on the Second Meeting of the International Health Regulations (2005) Emergency Committee Regarding the Outbreak of Novel Coronavirus (2019-nCoV). World Health Organization (WHO) (Press release). https://www.who.int/news-room/detail/23-01-2020-statement-on-themeeting-of-the-international-health-regulations-(2005)-emergency-committee-regarding-the-outbr eak-of-novel-coronavirus-(2019-ncov).

WHO. (2020d). WHO director-General's opening remarks at the media briefing on COVID19 - 11 march 2020. https://www.who.int/dg/speeches/detail/who-director-general-s-opening-remarks-at-the-media -briefing-on-covid-19---11-march-2020.

WHO. (2020e). WHO, 2020. https://www.who.int.

Zambrano-Monserrate, M. A., Ruano, M. A., \& Sanchez-Alcalde, L. (2020). Indirect effects of COVID19 on the environment. Science of the Total Environment, 728, 1-4. https://doi.org/10.1016/j.scito tenv.2020.138813.

Zhang, X., Wang, H., Che, H. Z., Tan, S. C., Shi, G. Y., \& Yao, X. P. (2020). The impact of aerosol on MODIS cloud detection and property retrieval in seriously polluted East China. Science of the Total Environment, 711, 134634. https://doi.org/10.1016/j.scitotenv.2019.134634.

Zhou, F., Yu, T., Du, R., et al. (2020). Clinical course and risk factors for mortality of adult inpatients with COVID-19 in Wuhan, China: a retrospective cohort study. Lancet, S0140-6736(20), 30566-30573. https://doi.org/10.1016/s0140-6736(20)30566-3.

Zhou, P., Yang, X.-L., Wang, X.-G., Hu, B., Zhang, L., Zhang, W., et al. (2020). Discovery of a novel coronavirus associated with the recent pneumonia outbreak in humans and its potential bat origin. BioRxiv. https://doi.org/10.1101/2020.01.22.914952.

Zhu, N., Zhang, D., Wang, W., Li, X., Yang, B., Song, J., et al. (2020). A novel coronavirus from patients with pneumonia in China, 2019. New England Journal of Medicine, 382, 727-733. https://doi. org/10.1056/NEJMoa2001017.

Publisher's Note Springer Nature remains neutral with regard to jurisdictional claims in published maps and institutional affiliations.

\section{Affiliations}

\section{Biswajit Bera ${ }^{1}$ D . Sumana Bhattacharjee ${ }^{2}$. Pravat Kumar Shit ${ }^{3}$ (D) Nairita Sengupta ${ }^{4}$. Soumik Saha ${ }^{5}$}

Sumana Bhattacharjee

sumana.aarohi@gmail.com

Pravat Kumar Shit

shitpravat2013@gmail.com

Nairita Sengupta

nairitasengupta2@gmail.com

Soumik Saha

soumiksaha577@gmail.com

1 Sidho-Kanho-Birsha University, P.O. Purulia, Ranchi Road, Purulia, West Bengal 723104, India

2 Department of Geography, University of Calcutta (Jogesh Chandra Chaudhuri College), 30, Prince Anwar Shah Road, Kolkata 700 033, India

3 Department of Geography, Raja Narendralal Khan Women's College, Gope Palace, P.O.

Vidyasagar University, Paschim Medinipur, Phulpahari, West Bengal 721102, India 
4 Department of Geography, Diamond Harbour Women’s University, Sarisha, West Bengal 743368, India

5 Independent Researcher, Department of Geography, University of Calcutta, Ballygunge, Kolkata, West Bengal 700019, India 